\title{
Seasonal in situ observations of glyoxal and methylglyoxal over the temperate oceans of the Southern Hemisphere
}

\author{
S. J. Lawson ${ }^{1}$, P. W. Selleck ${ }^{1}$, I. E. Galbally ${ }^{1}$, M. D. Keywood ${ }^{1}$, M. J. Harvey ${ }^{2}$, C. Lerot ${ }^{3}$, D. Helmig ${ }^{4}$, and Z. Ristovski ${ }^{5}$ \\ ${ }^{1}$ Commonwealth Scientific and Industrial Research Organisation, Oceans and Atmosphere Flagship, \\ Aspendale, Australia \\ ${ }^{2}$ National Institute of Water and Atmospheric Research, Wellington, New Zealand \\ ${ }^{3}$ Belgian Institute for Space Aeronomy, Brussels, Belgium \\ ${ }^{4}$ Institute of Arctic and Alpine Research, University of Colorado, Boulder, USA \\ ${ }^{5}$ International Laboratory for Air Quality \& Health, Queensland University of Technology, \\ Brisbane, Australia
}

Correspondence to: S. J. Lawson (sarah.lawson@csiro.au)

Received: 8 August 2014 - Published in Atmos. Chem. Phys. Discuss.: 25 August 2014

Revised: 16 November 2014 - Accepted: 25 November 2014 - Published: 12 January 2015

\begin{abstract}
The dicarbonyls glyoxal and methylglyoxal have been measured with 2,4-dinitrophenylhydrazine (2,4-DNPH) cartridges and high-performance liquid chromatography (HPLC), optimised for dicarbonyl detection, in clean marine air over the temperate Southern Hemisphere (SH) oceans. Measurements of a range of dicarbonyl precursors (volatile organic compounds, VOCs) were made in parallel. These are the first in situ measurements of glyoxal and methylglyoxal over the remote temperate oceans. Six $24 \mathrm{~h}$ samples were collected in summer (February-March) over the Chatham Rise in the south-west Pacific Ocean during the Surface Ocean Aerosol Production (SOAP) voyage in 2012, while $3424 \mathrm{~h}$ samples were collected at Cape Grim Baseline Air Pollution Station in the late winter (August-September) of 2011. Average glyoxal mixing ratios in clean marine air were $7 \mathrm{ppt}$ at Cape Grim and 23 ppt over Chatham Rise. Average methylglyoxal mixing ratios in clean marine air were $28 \mathrm{ppt}$ at Cape Grim and $10 \mathrm{ppt}$ over Chatham Rise. The mixing ratios of glyoxal at Cape Grim are the lowest observed over the remote oceans, while mixing ratios over Chatham Rise are in good agreement with other temperate and tropical observations, including concurrent Multi-Axis Differential Optical Absorption Spectroscopy (MAX-DOAS) observations. Methylglyoxal mixing ratios at both sites are comparable to the only other marine methylglyoxal observations available over the tropical Northern Hemisphere $(\mathrm{NH})$ ocean. Ratios of glyoxal : methylglyoxal $>1$ over Chatham Rise but $<1$ at Cape
\end{abstract}

Grim suggest that a different formation and/or loss processes or rates dominate at each site. Dicarbonyl precursor VOCs, including isoprene and monoterpenes, are used to calculate an upper-estimate yield of glyoxal and methylglyoxal in the remote marine boundary layer and explain at most $1-3 \mathrm{ppt}$ of dicarbonyls observed, corresponding to $10 \%$ and $17 \%$ of the observed glyoxal and 29 and $10 \%$ of the methylglyoxal at Chatham Rise and Cape Grim, respectively, highlighting a significant but as yet unknown production mechanism. Surface-level glyoxal observations from both sites were converted to vertical columns and compared to average vertical column densities (VCDs) from GOME-2 satellite retrievals. Both satellite columns and in situ observations are higher in summer than winter; however, satellite vertical column densities exceeded the surface observations by more than $1.5 \times 10^{14}$ molecules $\mathrm{cm}^{-2}$ at both sites. This discrepancy may be due to the incorrect assumption that all glyoxal observed by satellite is within the boundary layer, or it may be due to challenges retrieving low VCDs of glyoxal over the oceans due to interferences by liquid water absorption or the use of an inappropriate normalisation reference value in the retrieval algorithm. This study provides much-needed data to verify the presence of these short-lived gases over the remote ocean and provide further evidence of an as yet unidentified source of both glyoxal and also methylglyoxal over the remote oceans. 


\section{Introduction}

Natural aerosols, including sea spray and secondary aerosols originating from marine dimethyl sulfide (DMS), have been shown to strongly affect the uncertainty of cloud radiative forcing in global climate models, highlighting a need to understand the composition and microphysical properties of marine aerosol in very pristine marine environments (Carslaw et al., 2013). While primary emissions, including wind-blown sea salt, make a large contribution to aerosol mass in the remote marine boundary layer (MBL), organic carbon can make a significant contribution to the mass of submicron marine aerosol in the more biologically active summer months (O'Dowd et al., 2004; Facchini et al., 2008a; Sciare et al., 2009; Ovadnevaite et al., 2011b). This organic carbon may be primary organic matter, including polymer microgels, viruses, bacteria, colloids and organic detritus, directly transferred from bulk water and the sea surface microlayer (SML) of the ocean to the atmosphere during bubble burst (Orellana et al., 2011; Facchini et al., 2008b). The organic carbon may also comprise secondary aerosol, formed from the oxidation of gas phase oceanderived volatile organic compounds (VOCs) such as DMS, isoprene and monoterpenes (Shaw et al., 2010).

The organic component of marine aerosol is chemically complex and requires multiple state-of-the-art techniques to elucidate (Fu et al., 2011, 2013; Decesari et al., 2011; Rinaldi et al., 2010; Claeys et al., 2010). A further challenge is the more recent blurring of distinction between primary and secondary organics, in which oxidative ageing and evaporation of semivolatile primary organic aerosol (POA) leads to the production of gas phase, volatile, low molecular-weight products, which may then go to form secondary organic aerosol (SOA) (Donahue et al., 2014). The resulting photochemically processed POA may have similar chemical properties to, and is sometimes loosely classified as, SOA. (Rinaldi et al., 2010; Decesari et al., 2011; Ovadnevaite et al., 2011b). This interrelatedness of primary and secondary organics adds considerable complexity to understanding the formation and chemical processing of organic aerosols in the MBL.

The influence of organics on cloud condensation nuclei (CCN) activity of marine aerosol in general appears to be highly variable, and investigations have mostly focused on primary organic aerosol (Ovadnevaite et al., 2011a; Meskhidze et al., 2011; Orellana et al., 2011; Westervelt et al., 2012; Topping et al., 2013). The contribution of DMS oxidation products to the CCN population over the remote Southern Ocean has been well established (Korhonen et al., 2008; Ayers and Gras, 1991); however, an understanding of the contribution of other secondary aerosol species, such as isoprene and monoterpene-derived SOA, to the $\mathrm{CCN}$ activity of marine aerosol is still emerging. Meskhidze and Nenes et al. (2006) suggested a link between isoprene-derived SOA over a phytoplankton bloom site and cloud microphysical and radiative properties in the Southern Ocean, while Lana et al. (2012) found a correlation between modelled secondary sulfur and organic aerosols and the variability of cloud microphysics derived from satellite observations over the remote mid- and high-latitude ocean.

The $\alpha$-dicarbonyl glyoxal (CHOCHO) is an important SOA aerosol precursor, which in recent years has been found to be widespread in the marine boundary layer (MBL), both via column measurements (Lerot et al., 2010; Vrekoussis et al., 2009; Mahajan et al., 2014; Wittrock et al., 2006) and in situ measurements (Coburn et al., 2014). The dominant source of glyoxal is the oxidation of parent VOCs, with isoprene globally the most important precursor (explaining $47 \%$ of glyoxal formation) (Fu et al., 2008). Glyoxal has a global average lifetime of about $3 \mathrm{~h}$ (Fu et al., 2008; Myriokefalitakis et al., 2008; Stavrakou et al., 2009) and is highly water soluble and so can diffuse into aerosol or cloud water, where it is converted to SOA through the formation of low-volatility products such as organic acids and oligomers (Ervens et al., 2011; Kampf et al., 2013; Sedehi et al., 2013; Lee et al., 2011; Lim et al., 2013). $\alpha$-dicarbonyl methylglyoxal $\left(\mathrm{CHOCCH}_{3} \mathrm{O}\right)$, a close relative of glyoxal, also forms low-volatility products in the aqueous phase (Tan et al., 2012; Sedehi et al., 2013; Lim et al., 2013), has a short global lifetime of $1.6 \mathrm{~h}$ and is produced by oxidation of gas phase parent compounds, predominantly isoprene (Fu et al., 2008). The destruction of both dicarbonyls is mainly via photolysis, followed by reaction with $\mathrm{OH}$ (Myriokefalitakis et al., 2008; Fu et al., 2008). The global sources of glyoxal and methylglyoxal are significant $\left(45 \mathrm{Tg} \mathrm{Ca}^{-1}\right.$ and $140 \mathrm{Tg} \mathrm{a}^{-1}$ globally), and their SOA yield, which occurs mainly in clouds, is comparable in magnitude to SOA formation from other oxidation products of biogenic VOCs and aromatics (Fu et al., 2008). Major oxidation products of glyoxal and methylglyoxal at in-cloud relevant concentrations are oxalic and pyruvic acids (Lim et al., 2013).

There is considerable evidence that the dicarbonyls, and particularly glyoxal, make an important contribution to the organic component of marine aerosol over the remote oceans. Both dicarbonyls have been found in marine aerosols over the Atlantic Ocean (van Pinxteren and Herrmann, 2013) and Pacific Ocean (Bikkina et al., 2014), with dicarbonyl mass positively correlated to organic acids (including oxalic acid) and ocean biological activity. Oxalic acid has been consistently found in pristine marine aerosol from remote sites, including Amsterdam Island (Claeys et al., 2010), Mace Head (Rinaldi et al., 2010), Cape Verde (Muller et al., 2010) and Cape Grim (unpublished data), with highest concentrations during the biologically active summer months, coinciding with maximum concentrations of the DMS oxidation products methanesulfonic acid (MSA) and non-sea-salt sulfate. Rinaldi et al. (2011) reported that oxalic acid in submicron marine aerosol from Mace Head and Amsterdam Island showed a similar seasonal cycle to SCIAMACHY glyoxal 
columns, and a chemical box model was able to explain the observed oxalate using the glyoxal columns.

However, significant unknowns remain. There are currently insufficient methylglyoxal observations to confirm its presence and importance to SOA formation over the remote oceans, and understanding the source of the observed glyoxal in the MBL has proven challenging. If the production of glyoxal is indeed due only to the oxidation of precursor VOCs, calculating the expected yield of glyoxal should be straightforward in this relatively simple and well-mixed chemical matrix over the remote ocean. However, there has been the consistent suggestion that glyoxal concentrations in the MBL are in excess of the yields expected from its precursors. Wittrock et al. (2006) reported enhanced concentrations of formaldehyde and glyoxal from SCIAMACHY satellite retrievals over tropical oceans but were unable to reproduce observations using a global model. More detailed global modelling studies by Fu et al. (2008) and Myriokefalitakis et al. (2008) were also unable to reproduce SCIAMACHY glyoxal column retrievals over the tropical oceans, highlighting the possibility of unknown biogenic marine sources. Later satellite retrievals of glyoxal from SCIAMACHY (Vrekoussis et al., 2009), GOME-2 (Lerot et al., 2010) and recently from Ozone Monitoring Instrument (OMI) (Miller et al., 2014) have provided further evidence of the widespread presence and seasonal modulation of glyoxal over biologically active oceans, although in some regions, such as the temperate $\mathrm{SH}$ oceans, the columns are close to satellite detection limits.

Glyoxal and methylglyoxal were first observed in the atmosphere and seawater in the Caribbean and Sargasso seas as early as 1989 (Zhou and Mopper, 1990), where concentrations of glyoxal and methylglyoxal in seawater were 4 and 2 orders of magnitude too low to explain the atmospheric concentrations. MAX-DOAS retrievals observed hundreds of parts per trillion (ppt) glyoxal in the Gulf of Maine (Sinreich et al., 2007) and an average of 63 ppt glyoxal over the remote tropical Pacific (Sinreich et al., 2010). The Sinreich et al. (2010) measurements were sufficiently far from land that the glyoxal observed was either from unrealistically high mixing ratios of long-lived terrestrial precursors or, more likely, a substantial unknown source, possibly of marine origin, in support of earlier modelling and satellite studies. The widespread presence of glyoxal over the remote oceans was recently confirmed by Mahajan et al. (2014), who reported MAX-DOAS and long-path DOAS differential slant column densities from 10 field campaigns in both hemispheres in tropical and temperate regions. A global average value of about $25 \mathrm{ppt}$ was reported, with an upper limit of $40 \mathrm{ppt}$; however, over the Southern Hemisphere oceans, particularly in subtropical and temperate regions, glyoxal mixing ratios were mostly below instrument detection limits.

In 2014 an additional source of glyoxal in the MBL was identified in laboratory studies (Zhou et al., 2014), when oxidation of the sea surface microlayer (SML) led to the emission of low molecular-weight oxygenated compounds, including glyoxal. However, the atmospheric yields of glyoxal were low, attributed to the fast irreversible hydrolysis of glyoxal, which prevents the transfer of glyoxal to the atmosphere. Van Pinxteren and Herrmann (2013) observed a glyoxal enrichment factor of 4 in SML compared to the bulk ocean, but the concentration observed was several orders of magnitude too low to explain the mixing ratios of $10 \mathrm{~s}$ of ppt typically seen in the MBL (Sinreich et al., 2010). The first eddy-covariance flux measurements of glyoxal were recently made over the oceans, using an in situ Fast Light Emitting Diode Cavity Enhanced Differential Optical Absorption Spectroscopy (LED-CE-DOAS instrument) (Coburn et al., 2014). Negative flux (glyoxal transfer into the ocean) was observed in both hemispheres during the day and a positive flux from the ocean in the SH at night. However, despite this first evidence of a direct oceanic source of glyoxal to the atmosphere, the positive flux at night could explain only $4 \mathrm{ppt}$ of the glyoxal observed in the overlying atmosphere (some $30 \%$ of the overnight increase), implying the contribution of another night-time production mechanism.

Despite these recent advances in our understanding of glyoxal production processes, our current inability to reconcile the presence of these short-lived gases over the remote ocean suggests we have not identified a significant source of glyoxal. It is likely that this unidentified source also contributes to the glyoxal production in polluted terrestrial environments but is masked by a large contribution from anthropogenic precursors such as acetylene. The production of glyoxal from the photochemical processing of organic aerosol is a possible contributor (Vrekoussis et al., 2009; Stavrakou et al., 2009; Bates et al., 2012) though this remains unconfirmed. An additional source may be the entrainment of glyoxal and its precursors from the free troposphere into the MBL, particularly in light of recent observations of non-negligible mixing ratios of glyoxal in the free troposphere (Volkamer, 2014).

A more in-depth understanding is currently hindered by a lack of dicarbonyl observations in the MBL. While recent studies have contributed substantial additional observations of glyoxal over the remote oceans (Coburn et al., 2014; Mahajan et al., 2014), there have been no studies which have made parallel measurements of gas phase precursors, and so expected yields of glyoxal are only estimates. No in situ observations of glyoxal have been reported over the temperate oceans of either hemisphere, and there is only one previous study reporting methylglyoxal observations over the world's oceans (in the tropical Northern Hemisphere, NH) (Zhou and Mopper, 1990). With the exception of the Caribbean and Sargasso Sea measurements (Zhou and Mopper, 1990), all column and in situ observations of glyoxal over the remote oceans have used optical measurement techniques (Mahajan et al., 2014; Sinreich et al., 2007, 2010; Coburn et al., 2014). Finally, given the challenges in retrieving low VCDs (vertical column densities) of glyoxal over the ocean from satellite ob- 


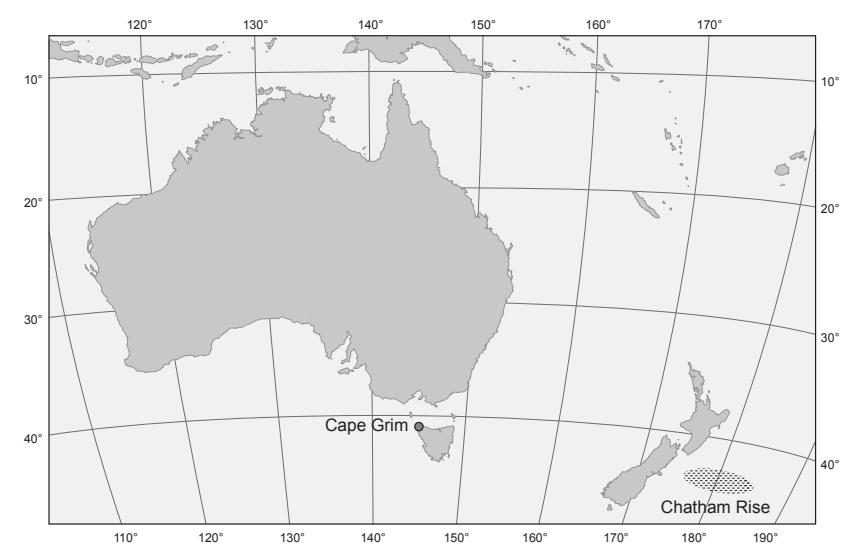

Figure 1. Cape Grim and Chatham Rise sampling locations.

servations (Lerot et al., 2010; Vrekoussis et al., 2009; Miller et al., 2014), more ground-based measurements are required.

We provide much-needed in situ glyoxal and methylglyoxal data from the very sparsely measured temperate oceans of the Southern Hemisphere. Observations have been made using the derivatisation of dicarbonyls on 2,4-DNPH cartridges and analysis with HPLC, which is an alternative measurement technique to the optical techniques used widely for oceanic glyoxal observations to date. Measurements have been made in two seasons - summer and winter - and auxiliary measurements, including carbon dioxide, radon and particles, have been used to conclusively remove the possibility of any terrestrial influence on the dicarbonyl observations. This is the first study to concurrently measure a range of dicarbonyl precursors (VOCs) so that the yield of dicarbonyls from its gas phase precursors can be conclusively determined. Finally, we provide the first methylglyoxal observations over the temperate remote ocean.

\section{Methods}

\subsection{Sampling locations}

Dicarbonyl in situ observations were made at the Cape Grim Baseline Air Pollution Station (CGBAPS) and during a voyage over the Chatham Rise in the south-west Pacific Ocean during the Surface Ocean Aerosol Production (SOAP) study (see Fig. 1).

\subsubsection{Cape Grim Baseline Air Pollution Station}

The CGBAPS is located on the north-west tip of the island state of Tasmania, Australia $\left(40.683^{\circ} \mathrm{S} 144.689^{\circ} \mathrm{E}\right)$. CGBAPS is a World Meteorological Organisation (WMO) Global Atmosphere Watch (GAW) Global Station and hosts a wide variety of long-term measurements including greenhouse gases, ozone-depleting substances, aerosols, radon and reactive gases. The station is situated on a cliff $94 \mathrm{~m}$ above sea level, and when the wind blows from the south-westerly "baseline" sector the air that arrives at the station has travelled over the Southern Ocean several days previously, with no terrestrial influence (see Sect. 2.2.2.)

A total of 33 samples were collected from the 26 August to 29 September in 2011 (late winter-early spring). Each $24 \mathrm{~h}$ sample consisted of approximately $2000 \mathrm{~L}$ of air drawn through a 2,4-DNPH S10 Cartridge (Supelco) at a flow rate of $1.8 \mathrm{~L} \mathrm{~min}^{-1}$.

Ambient air was sampled down a $150 \mathrm{~mm}$ diameter stainless steel inlet stack which extends $10 \mathrm{~m}$ above the roof deck and is 104 ma.s.l. The flow rate of the intake was $235 \mathrm{~L} \mathrm{~min}^{-1}$ to ensure laminar flow was maintained. The DNPH cartridges were loaded in a custom-designed "sequencer" which allows up to 16 cartridges to be automatically sampled for a predefined time and sequence. The sequencer drew air via a $3 \mathrm{~m}$ length of 1/4 inch PFA tubing, which was extended into the centre of the stainless steel intake stack. Samples were collected in all wind directions and an ozone scrubber (KI-impregnated filter) was placed in front of the cartridges. Chlorophyll $a$, a measure of ocean biological activity, is low in the Southern Ocean in winter, with typical values of $0.1-0.2 \mathrm{mg} \mathrm{m}^{-3}$ (Bowie et al., 2011). Air temperatures throughout the sampling period ranged from 7 to $13^{\circ} \mathrm{C}$, with an average of $10^{\circ} \mathrm{C}$, and total rainfall during the sample period at the station was $90 \mathrm{~mm}$. The average relative humidity was $78 \%$.

Data collected from concurrent and continuous carbon dioxide, particle count and radon measurements at Cape Grim have been included in this work as indicators of clean marine air (see Sect. 2.2.2). VOC data from canister samples collected at Cape Grim for the NOAA Halocarbon and other Atmospheric Trace Species (HATS) group and the Carbon Cycle Network have been used to calculate dicarbonyl yields (see Sect. 2.2.3)

\subsubsection{Surface Ocean Aerosol Production (SOAP) voyage}

The Surface Ocean-Lower Atmosphere Study (SOLAS)endorsed Surface Ocean Aerosol Production study in 2012 investigated links between ocean biogeochemistry, air-sea exchange of trace gases and particles, and the composition of the overlying atmosphere (Landwehr et al., 2014). Measurements were made on board the RV Tangaroa over Chatham Rise, located over the biologically productive subtropical oceanic front. Six dicarbonyl samples were collected from the 29 February to 6 March 2012 (late summer). Each $24 \mathrm{~h}$ sample consisted of approximately $1400 \mathrm{~L}$ of air drawn through a 2,4-DNPH S10 Cartridge (Supelco) at a flow rate of $1.3 \mathrm{~L} \mathrm{~min}^{-1}$. Cartridges were loaded in the sequencer which drew air off a $25 \mathrm{~m} 3 / 8$ inch PFA inlet line with a flow rate of $10 \mathrm{~L} \mathrm{~min}^{-1}$. Inlet losses were determined to be $<2 \%$ for isoprene, monoterpenes, methanol and dimethyl sulfide; however, losses were not specifically tested for dicarbonyls 
due to the absence of a gaseous calibration standard. The sample inlet line pulled air from the crow's nest of the vessel above the bridge, some $28 \mathrm{~m}$ a.s.l. To avoid ship exhaust from aft of the inlet being drawn into the PFA inlet line and sampled on to the cartridges, a baseline switch was developed and deployed using a CR3000 micrologger control system (Campbell Scientific, Logan UH). The switch used $1 \mathrm{~Hz}$ wind data from the vessel's port/starboard pair of WindObserver anemometers (Gill Instruments, Lymington, UK) and was configured to switch pumps off within $1 \mathrm{~s}$ of detecting non-baseline conditions. The baseline was defined as a 5second running average relative wind speed $>3 \mathrm{~ms}^{-1}$ and a $5 \mathrm{~s}$ vector-averaged relative wind direction outside the aft ( $135^{\circ}$ to $225^{\circ}$ relative degrees) wind direction, with a meteorological convention of $0^{\circ}$ at the bow. A 5-minute duration under accepted wind speed and direction was required before turning on the instrument. During experimentation and for much of the "steaming" transit legs, the vessel was oriented into the wind for as much of the time as possible in addition to dedicated periods of steaming into the wind. This resulted in a high frequency $(\sim 75 \%)$ of baseline conditions throughout the voyage.

During the voyage, three distinct phytoplankton blooms were sampled, and dicarbonyl samples reported in this work were taken over the third bloom during the last 6 days of the voyage. Underway chlorophyll $a$ during this period ranged between 0.3 and $0.9 \mathrm{mg} \mathrm{m}^{-3}$ (10-90th percentile) with a median of $0.5 \mathrm{mg} \mathrm{m}^{-3}$ (calibrated against discrete data with data corresponding to sky irradiance $>50 \mathrm{~W} \mathrm{~m}^{2}$ removed, i.e. to exclude daytime data affected by photoquenching). The bloom consisted of a mixed phytoplankton population of coccolithophores, small flagellates and dinoflagellates and had a deep cold mixed layer characteristic of subantarctic waters. During the 6 days of sampling, the vessel moved between $44.928^{\circ} \mathrm{S}$ and $41.261^{\circ} \mathrm{S}$ and $172.768^{\circ} \mathrm{E}$ and $175.168^{\circ} \mathrm{E}$, including transiting to Lyttelton Port on the east coast of the South Island of New Zealand for several hours on the 1st March to exchange staff. However, due to south-westerly winds during this period and high wind speeds (average of $13 \mathrm{~m} \mathrm{~s}^{-1}$ and max of $29 \mathrm{~m} \mathrm{~s}^{-1}$ ), air was predominantly of marine origin. Air temperatures during the sampling period ranged from $10-18^{\circ} \mathrm{C}$ with an average of $13^{\circ} \mathrm{C}$, and total rainfall during the 6 -day sample period was $3.0 \mathrm{~mm}$. The average relative humidity was $80 \%$ during the voyage.

Parallel measurements also made during the SOAP voyage, which have been utilised in this work, include online VOCs via proton transfer reaction mass spectrometry (PTRMS) (see Sect. 2.2.3) and carbon dioxide and particle concentrations (Sect. 2.2.2).

\subsection{In situ measurements}

\subsubsection{DNPH cartridges and HPLC analysis}

During sampling, carbonyls and dicarbonyls were trapped on S10 Supelco cartridges, containing high-purity silica adsorbent coated with 2,4-dinitrophenylhydrazine (2,4-DNPH), where they were converted to the hydrazone derivatives. Samples were refrigerated immediately after sampling until analysis. The derivatives were extracted from the cartridge in $2.5 \mathrm{~mL}$ of acetonitrile and analysed by a highperformance liquid chromatography (HPLC) system consisting of a Dionex GP40 gradient pump, a Waters 717 autosampler, a Shimadzu System controller SCL-10A VP, a Shimadzu diode array detector (DAD) SPD-M10A VP, a Shimadzu Column Oven CTO-10AS VP and Shimadzu CLASS-VP chromatography software. The compound separation was performed with two Supelco Supelcosil LC-18 columns in series $(5 \mu \mathrm{m}, 4.6 \mathrm{~mm}$ ID $\times 250 \mathrm{~mm}$ in length, Part No 58298). The chromatographic conditions include a flow rate of $1.6 \mathrm{~mL} \mathrm{~min}^{-1}$ and an injection volume of $25 \mu \mathrm{L}$, and the DAD was operated in the $220 \mathrm{~nm}$ to $520 \mathrm{~nm}$ wavelength range. The peaks were separated by gradient elution with an initial mobile phase of $64 \%$ acetonitrile and $36 \%$ deionised water for $10 \mathrm{~min}$, followed by a linear gradient to $100 \%$ acetonitrile for $20 \mathrm{~min}$ and with a column temperature of $30^{\circ} \mathrm{C}$. The deionised water used for analysis was $18.2 \mathrm{M} \Omega \mathrm{cm}$ grade produced from a Millipore Milli-Q Advantage 10 system and HPLC-grade acetonitrile was purchased from Merck.

Standards for glyoxal and methylglyoxal were prepared by making hydrazone crystals from glyoxal (40\% wt in $\mathrm{H}_{2} \mathrm{O}$ ), methylglyoxal (40\% wt in $\mathrm{H}_{2} \mathrm{O}$ ) and derivatisation reagent 2,4-DNPH (all from Sigma-Aldrich). The crystals were weighed and dissolved in acetonitrile to produce a stock standard for the glyoxal and methyglyoxal derivatives, which was used to make up a range of standards from 0.125 to $1.000 \mu \mathrm{g} \mathrm{mL}^{-1}$ which gave a linear response with a correlation coefficient of 0.999 for both derivatives.

The DAD enables the absorption spectra of each peak to be determined. The monocarbonyl DNPH derivatives all have a similarly shaped absorption spectrum with a maximum absorption near $360 \mathrm{~nm}$. In contrast, the dicarbonyls glyoxal and methylglyoxal have absorption spectra which differ in shape to the monocarbonyls and have a maximum absorption near $435 \mathrm{~nm}$ (Fig. 2). The difference in the spectra highlights which peaks in the chromatograms are mono- or dicarbonyl DNPH derivatives and, along with retention times, allows the identification of the glyoxal and methylglyoxal peaks. Quantifying the dicarbonyl DNPH derivatives at $435 \mathrm{~nm}$ results in increased peak height and also has the added benefit of reducing the peak area of any co-eluting mono-carbonyl DNPH derivatives (Fig. 3). All samples, blanks and standards for glyoxal and methylglyoxal in this work were quantified using absorption at $435 \mathrm{~nm}$, which, as discussed above, is optimised for dicarbonyl detection. 


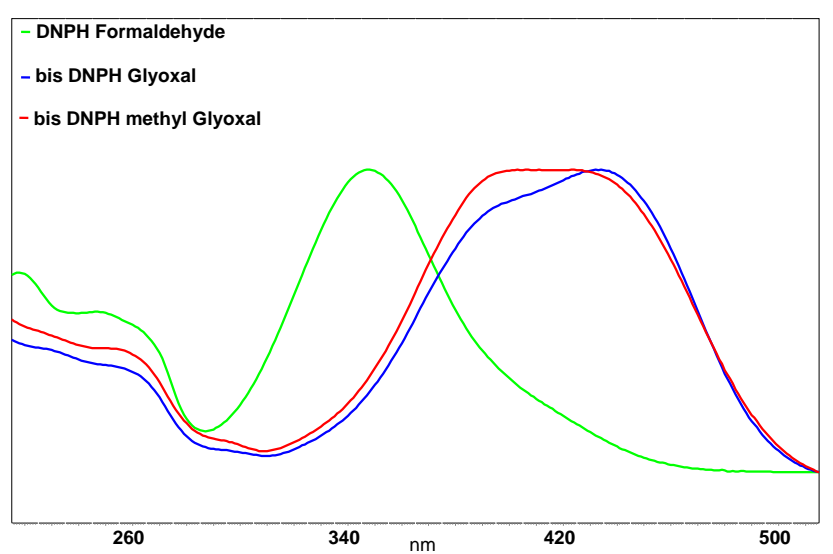

Figure 2. Absorption spectra for monocarbonyl formaldehyde (green), dicarbonyls glyoxal (blue line) and methylglyoxal (red line).

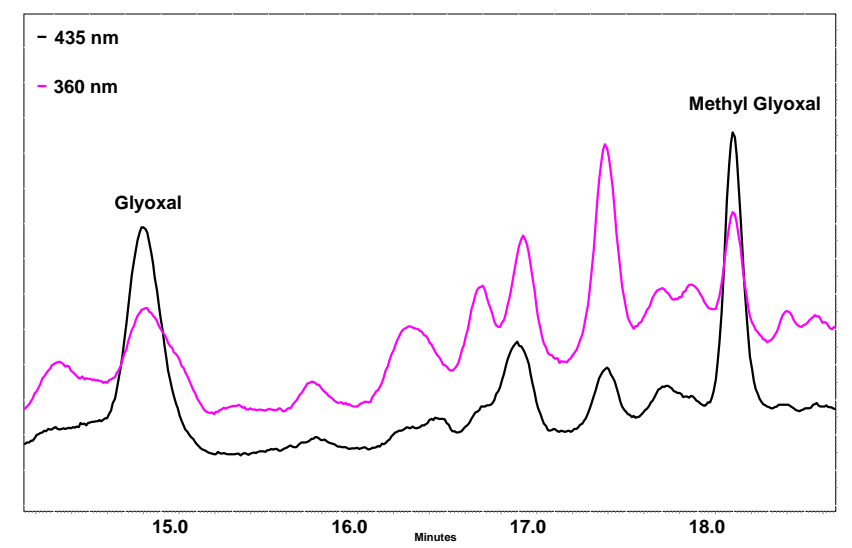

Figure 3. Example of sample chromatogram from Chatham Rise, using absorption at $360 \mathrm{~nm}$ (pink line) and $435 \mathrm{~nm}$ (black line).

Sample recovery was determined by spiking $1 \mu \mathrm{g}$ of glyoxal and methylglyoxal onto DNPH cartridges - recoveries were $96 \pm 0.3 \%$ for glyoxal and $111 \pm 8 \%$ for methylglyoxal. The degree of derivatisation was examined in these spiked cartridges to ensure both carbonyl groups in the glyoxal and methylglyoxal molecules had reacted with the 2,4DNPH (Wang et al., 2009; Olsen et al., 2007). Analysis of samples that had been extracted within the last 24 h showed a second smaller peak, indicating that $\sim 5 \%$ of the glyoxal had reacted to form mono-derivatives rather than bis-derivatives (e.g. only one carbonyl group had reacted). However analysis of samples that were held for $>24 \mathrm{~h}$ after extraction showed all of the mono-derivative had been converted into the bisderivative. As all samples were extracted and then held for at least $24 \mathrm{~h}$ before analysis; complete derivatisation to the bis-derivative is expected. For methylglyoxal there was no evidence of any mono-derivatives. The total mass of carbonyls and dicarbonyls sampled on the DNPH cartridges was at most $7 \%$ of the cartridge capacity, and collection efficien-
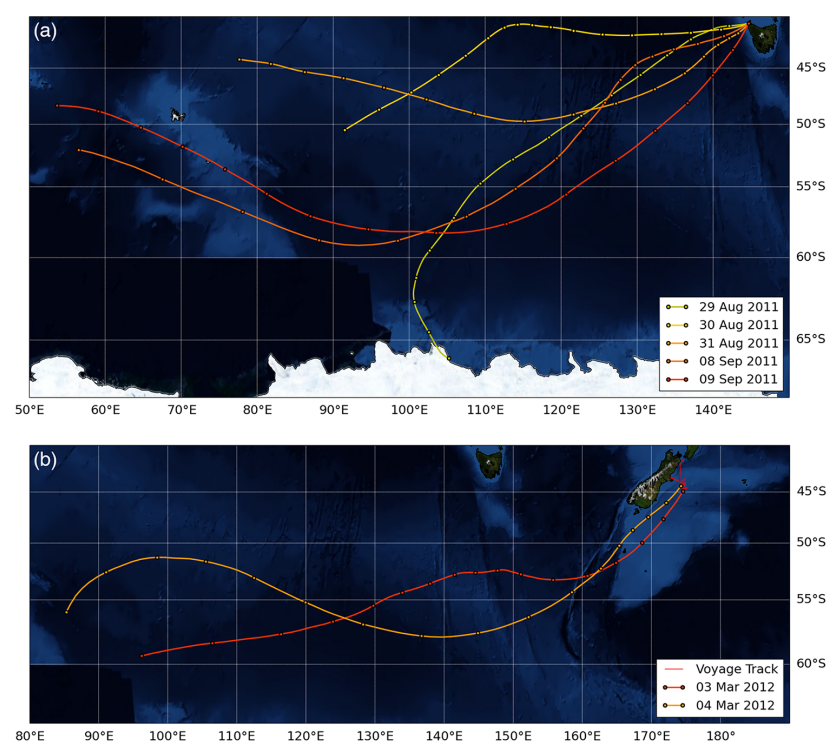

Figure 4. (a) HYSPLIT 96-hour back trajectory for the five clean marine samples from Cape Grim. (b) HYSPLIT 96-hour back trajectory for the two clean marine samples from the SOAP Voyage (Chatham Rise).

cies of $>93 \%$ have been determined for carbonyls on DNPH cartridges at similar flow rates to those used here (Zhang et al., 1994; Slemr, 1991; Grutter et al., 2005). Hence, no significant losses of dicarbonyls during sampling are expected.

The minimum detectable limit (MDL) for glyoxal and methylglyoxal was calculated from the standard deviation of field blanks collected during the study period, based on the principles of ISO 6879 (ISO, 1995). Field blanks were opened and installed in the sequencer sampling train for the same time period as the samples. MDLs for a $24 \mathrm{~h} \mathrm{sam-}$ ple were $1 \mathrm{ppt}$ (glyoxal) and $1.7 \mathrm{ppt}$ (methylglyoxal) during SOAP and $0.6 \mathrm{ppt}$ (glyoxal) and $0.9 \mathrm{ppt}$ (methylglyoxal) at Cape Grim. Glyoxal and methylglyoxal mixing ratios were above MDLs in all $24 \mathrm{~h}$ samples.

\subsubsection{Supporting measurements for the selection of clean marine periods}

HYSPLIT (https://ready.arl.noaa.gov/HYSPLIT.php) $96 \mathrm{~h}$ air-mass back trajectories ( $300 \mathrm{~m}$ a.s.l.) were used as an additional means of identifying clean marine samples from Cape Grim and the Chatham Rise (see Fig. 4). Specific surface measurements used to indicate clean marine air for each site are discussed below.

\section{Cape Grim}

Atmospheric radon-222, carbon dioxide and particle concentration data were used to select dicarbonyl samples with clean marine origin and no terrestrial influence. 
Atmospheric radon-222 is a useful atmospheric tracer to determine the degree of contact between an air parcel and a terrestrial surface, due to the much larger flux of radon from terrestrial surfaces compared with the ocean. Hourly atmospheric radon-222 measurements at Cape Grim are made on air taken from a $70 \mathrm{~m}$ inlet (height above sea level $164 \mathrm{~m}$ ) and using the dual-flow loop two-filter method. See Zahorowski et al. (2013) for details of the measurement technique and the application of radon data to identify clean marine air.

Carbon dioxide $\left(\mathrm{CO}_{2}\right)$ concentrations may be used to indicate whether an air mass is primarily of marine origin or has had recent contact with land. Terrestrial contact results in enhancement or drawdown of $\mathrm{CO}_{2}$, depending on the land use and anthropogenic sources. Continuous $\mathrm{CO}_{2}$ measurements at Cape Grim are sampled via a $70 \mathrm{~m}$ inlet and measured via a continuous, ultraprecise CSIRO LoFlo NDIR system, described elsewhere (Steele et al., 2014). Hourly averaged $\mathrm{CO}_{2}$ concentrations were used in this work.

Particle concentration may be used as an indicator of an air mass history, as recent contact with a terrestrial surface leads to particle concentrations enhanced above the low concentrations typically found in marine air. Measurements of condensation nuclei $(\mathrm{CN})$ greater than $10 \mathrm{~nm}$ in diameter $(\mathrm{CN}>10 \mathrm{~nm})$ are made at Cape Grim using a $3010 \mathrm{CPC}$ TSI particle counter, sampling from the $10 \mathrm{~m}$ sample inlet described in Sect. 2.1.1 (Gras, 2009). Hourly averaged particle concentration data was used in this work.

\section{Baseline status at Cape Grim}

Air is automatically classified as baseline at Cape Grim (e.g. clean marine air) using a combination of wind direction $\left(190^{\circ}\right.$ and $\left.280^{\circ}\right)$ and a seasonally adjusted particle concentration $(\mathrm{CN}>10 \mathrm{~nm})$ threshold based upon the previous 5 years' particle concentration data (Keywood, 2007). This baseline status was used to identify clean marine samples.

\section{SOAP Voyage}

Carbon dioxide and particle concentrations $(\mathrm{CN}>10 \mathrm{~nm})$ were used to identify dicarbonyl samples with a clean marine origin and no terrestrial influence during the voyage.

Carbon dioxide $\left(\mathrm{CO}_{2}\right)$ measurements were made continuously, using Picarro cavity ringdown spectroscopy (CRDS). The instrument was calibrated before and during the voyage using three reference calibration tanks. The $\mathrm{CO}_{2}$ intake through $6 \mathrm{~mm}$ Decabon tubing, from alongside the crow's nest, had a flow rate of $300 \mathrm{~mL} \mathrm{~min}^{-1}$.

Concentrations of $\mathrm{CN}>10 \mathrm{~nm}$ were measured with a 3010 CPC TSI particle counter. Antistatic (copper-coil) polyurethane ducting was used as a common aerosol inlet and sampled air from the main radar tower at $21 \mathrm{~m}$ height above sea level. The inlet was $10 \mathrm{~cm}$ in diameter and $30 \mathrm{~m}$ in length, with a flow rate of $800 \mathrm{~L} \mathrm{~m}^{-1}$. The CPC intake was connected to the common aerosol inlet via $1 / 4$ inch stainless steel tubing. Inlet loss tests indicated particle loss rates were $\sim 15 \%$ for total particle counts.

\subsubsection{Measurements for dicarbonyl yield calculations}

A high-sensitivity PTR-MS (Ionicon Analytik) was used to measure VOCs in real time during the SOAP voyage. Details of PTR-MS measurements are given in Galbally et al. (2007), and some additional information is provided here.

The PTR-MS ran with an inlet and drift tube temperature of $60{ }^{\circ} \mathrm{C}$, a $600 \mathrm{~V}$ drift tube and $\sim 2.2$ mbar drift tube pressure, which equates to an energy field of $133 \mathrm{Td}$. The $\mathrm{O}_{2}+$ signal was $<1 \%$ of the primary ion $\mathrm{H}_{3} \mathrm{O}^{+}$signal. The PTRMS sampled from a 25 m PFA 3/8 inch inlet line, which had a continuous flow of $10 \mathrm{~L} \mathrm{~min}^{-1}$, except during "non baseline" periods, when the inlet pump switched off and the PTRMS sampled room air through a VOC scrubber. The baseline status was logged on two separate programs and PCs, and so room air measurements were removed from the data. The PTR-MS measured in scan mode in the range of $\mathrm{m} / \mathrm{z}$ $21-m / z 155$ with a dwell time of $10 \mathrm{~s}$ per mass, allowing three full scans of the mass range per hour. The measurement of background signal resulting from interference ions and outgassing of materials was achieved by passing ambient air through a platinum-coated glass wool catalyst at $350^{\circ} \mathrm{C}$ for 30 min 4 times per day. An interpolated background signal was used for background correction. All species used in this work were calibrated daily by introducing a known flow of calibration gas to VOC-free ambient air which had previously passed through the catalyst. Calibrations and background measurements were carried out using an automated calibration system; see Galbally et al. (2007). Calibration gases used were $\sim 1$ ppm custom VOC mixture in nitrogen Apel Riemer ( $\sim 1 \mathrm{ppm}$ acetone, benzene, toluene, $m$-xylene, $\alpha$-pinene) and a custom gas mixture from Scott Specialty Gases ( $\sim 1$ ppm isoprene and 1,8-cineole).

The MDL for a single $10 \mathrm{~s}$ measurement of a selected mass was determined using the principles of ISO 6879 (ISO, $1995)$, i.e. $5 \%$ of the $10 \mathrm{~s}$ background measurements give a false positive reading. MDLs were as follows: $m / z$. 59 (acetone) $17 \mathrm{ppt}, \mathrm{m} / \mathrm{z} 69$ (isoprene) $28 \mathrm{ppt}$ and $\mathrm{m} / \mathrm{z} 79$ (benzene) $16 \mathrm{ppt}, \mathrm{m} / \mathrm{z} 93$ (toluene) $16 \mathrm{ppt}, \mathrm{m} / \mathrm{z} 107$ (sum xylenes) $19 \mathrm{ppt}, \mathrm{m} / z 137$ (sum monoterpenes) $66 \mathrm{ppt}$. In contrast to the first week of the voyage, the mixing ratios of VOCs during the last 6 days of the voyage were low, and subsequently many of the VOCs were below detection limit. The percentage of observations above MDL during this period are as follows: $m / z 59-95 \% ; m / z 69-14 \% ; m / z 79-15 \% ; m / z$ $93-14 \% ; m / z 107-7 \% ; m / z 137-4 \%$. Where the observation was lower than MDL, the half MDL value was substituted. Hence, due to the high periods of time that VOCs were below MDLs, the reported concentrations used for yield calculation are strongly influenced by the MDL. Reported mixing ratios of dicarbonyl precursors and dicarbonyl yields cal- 
culated with PTR-MS data (Sect. 2.5) are therefore likely to be an upper limit.

\section{VOC Flask data}

VOCs measurements from flasks collected at Cape Grim in baseline conditions were used to provide supplementary mixing ratios for species which were not targeted or could not be measured with sufficient sensitivity by PTR-MS at Cape Grim and during the SOAP voyage.

Stainless steel and glass flasks have been analysed by the National Oceanic Atmospheric Administration (NOAA) Earth System Research Laboratory (ESRL) Global Monitoring Division (GMD) Halocarbons (HATS) group with Gas Chromatography (GC) techniques since the early 1990s (Montzka et al., 2014). In this work, benzene and acetylene mixing ratios (analysed with GC mass spectrometry detection (Rhoderick et al., 2014; Pétron et al., 2012)) from August to September 2011 were utilised, as well as acetylene values from March 2011, as a proxy for mixing ratios during SOAP. Benzene values are calculated from an average of six pairs of flasks (two glass and four stainless steel pairs), while acetylene values are from three pairs of stainless steel flasks in August-September 2011 and a single pair of stainless steel flasks in March 2011. There is low interannual variability in benzene and acetylene at Cape Grim, so the values used, which correspond to the same sample periods as dicarbonyls, were representative of typical values for these months.

Glass flasks collected in baseline air at Cape Grim for the NOAA Carbon Cycle Group are analysed for VOCs by an automated gas chromatography system at the University of Colorado's Institute of Arctic and Alpine Research (INSTAAR) (Helmig et al., 2014; Helmig et al., 2009). Average propane, iso-butane, $n$-butane, iso-pentane and $n$-pentane mixing ratios were utilised from five pairs of glass flasks collected in August-September 2011 (filtered data). Flask data were also used to estimate alkane mixing ratios during the SOAP voyage (average mixing ratios from flasks sampled in March between 2005 and 2014). The following number of flasks were used in calculating average values for March: propane -4 pairs and 2 single flasks; $n$-butane -9 pairs and 4 single flasks; $i$ so-butane -10 pairs and 2 single flasks; $n$-pentane -7 pairs and 2 single flasks; and $i$ so-pentane -10 pairs and 2 single flasks.

Additional VOC measurements from Cape Grim were utilised for the dicarbonyl yield calculations, including online PTR-MS measurements in clean air at Cape Grim in February (summer) 2006 (Galbally et al., 2007), online PTRMS measurements in clean air in spring (November) 2007 (Lawson et al., 2011), in which data has been further filtered to include only baseline hours (Sect. 2.2.2), and stainless steel canisters which were collected at Cape Grim between 1998 and 2000 and analysed at Aspendale with GC with flame ionisation detection (FID) (Kivlighon, 2001). Further details of how these data were utilised is provided in Sect. 3.3 and Table 3.

\section{$\mathrm{OH}$ and ozone concentrations}

Precursor (VOC) lifetimes at Chatham Rise and Cape Grim were calculated using estimated $\mathrm{OH}$ concentrations and measured ozone mixing ratios from Cape Grim in March and August-September, respectively. $[\mathrm{OH}]$ was estimated from a simple steady-state chemical model where

$\mathrm{O}_{3} \stackrel{J\left(\mathrm{O}^{1} \mathrm{D}\right)}{\longrightarrow} \mathrm{O}_{2}+\mathrm{O}\left({ }^{1} \mathrm{D}\right)$

$\mathrm{O}\left({ }^{1} \mathrm{D}\right)+\mathrm{H}_{2} \mathrm{O} \rightarrow 2 \mathrm{OH}$.

$\mathrm{OH}$ is presumed to be removed overwhelmingly by reaction with carbon monoxide, and methane (Sommariva et al., 2004). $J\left(\mathrm{O}^{1} \mathrm{D}\right)$ is estimated from UV-B measurements for 2000-2005 inclusive (Wilson, 2014). All other chemical parameters are measured at Cape Grim (hourly averages), except for ozone, where climatological values were used. The full temperature dependence of reaction rates was used.

Average measured ozone mixing ratios in baseline air at Cape Grim were taken from Molloy et al. (2014).

\section{Results and discussion}

\subsection{In situ observations in clean marine air}

\subsubsection{Selection of clean marine samples}

Five of the 33 samples from Cape Grim and 2 of the 6 samples from Chatham Rise were identified as coming from clean marine back trajectory air over the $24 \mathrm{~h}$ sampling period. Mixing ratios of glyoxal and methylglyoxal at Cape Grim and Chatham Rise in clean marine air alongside supporting measurements are shown in Table 1. Air mass back trajectories $(96 \mathrm{~h})$ for these clean marine samples are shown in Fig. 4.

Samples were identified as being of clean marine origin in the following way. Samples from Cape Grim were initially identified as those for which $>90 \%$ of the sample hours were classified as baseline according to the criteria described in Sect. 2.2.2. Between 92 and $97 \%$ of the sampling time was baseline for the clean marine samples. Chatham Rise clean marine samples were initially identified using the HYSPLIT air mass back trajectories and in situ measured wind direction. As an additional indicator of clean marine baseline air, concurrent measurements of in situ continuous $\mathrm{CO}_{2}$ and $\mathrm{CN}>10 \mathrm{~nm}$ were calculated for Cape Grim and SOAP samples (see Table 1). Concurrent atmospheric radon-222 concentrations were also calculated for Cape Grim samples.

The pristine marine nature of these samples is clearly demonstrated by these supporting measurements. The particle concentration $(\mathrm{CN}>10 \mathrm{~nm})$ at Cape Grim during sampling of clean marine samples was 194 particles $\mathrm{cm}^{-3}$, 
Table 1. Mixing ratios of glyoxal and methylglyoxal in clean marine air at Cape Grim and Chatham Rise, with supporting measurements of carbon dioxide, condensation nuclei $(\mathrm{CN})>10 \mathrm{~nm}$ and atmospheric radon-222. Values are average \pm SD. $n$ stands for the number of $24 \mathrm{~h}$ samples.

\begin{tabular}{|c|c|c|c|c|c|c|c|}
\hline Site & Season & $\begin{array}{l}\text { Glyoxal } \\
\text { (ppt) }\end{array}$ & $\begin{array}{l}\text { Methylglyoxal } \\
\text { (ppt) }\end{array}$ & $\begin{array}{l}\mathrm{CO}_{2} \\
(\mathrm{ppm})\end{array}$ & $\begin{array}{c}\mathrm{CN}>10 \mathrm{~nm} \\
\left(\text { particles } \mathrm{cm}^{-3}\right)\end{array}$ & $\begin{array}{c}\text { Radon } \\
\left(\mathrm{mBq} \mathrm{m}^{-3}\right)\end{array}$ & $\begin{array}{c}\% \text { Baseline } \\
\text { hours }\end{array}$ \\
\hline $\begin{array}{l}\text { Cape Grim } \\
n=5\end{array}$ & $\begin{array}{l}\text { Winter/spring } \\
\text { (Aug-Sep) }\end{array}$ & $7 \pm 2$ & $28 \pm 11$ & $388.84 \pm 0.12$ & $194 \pm 110$ & $43 \pm 14$ & 95 \\
\hline $\begin{array}{l}\text { SOAP voyage } \\
n=2\end{array}$ & $\begin{array}{l}\text { Summer } \\
\text { (Feb-Mar) }\end{array}$ & $23 \pm 8$ & $10 \pm 10$ & $388.54 \pm 0.82$ & $328 \pm 1591$ & $\mathrm{n} / \mathrm{a}$ & $\mathrm{n} / \mathrm{a}$ \\
\hline
\end{tabular}

lower than the typical concentration of $\sim 400$ particles $\mathrm{cm}^{-3}$ in baseline air in August/September (Gras, 2014). Particle concentrations corresponding to the Chatham Rise clean marine samples are also low (328 particles $\mathrm{cm}^{-3}$ ) but with a large standard deviation of 1591 particles $\mathrm{cm}^{-3}$. This is due to short-lived, major enhancements (up to 30000 particles $\mathrm{cm}^{-3}$ ) of $\mathrm{CN}$, which correspond to measured enhancements in black carbon, identifying ship exhaust. This raises the possibility that there may have been a minor influence of ship exhaust on the VOC measurements, even though the VOC and aerosol inlets were not co-located. While glyoxal and methylglyoxal have been identified in medium-duty diesel exhaust (Schauer et al., 1999), and so could be emitted by the ship's diesel engine, Schauer et al. (1999) showed that oxygenated VOCs such as acetaldehyde and acetone were present in mixing ratios 10-20 times higher than glyoxal. No coincident spike in acetaldehyde or other VOCs were seen with the particle peaks; therefore, it is unlikely that ship exhaust had any influence on the glyoxal or methylglyoxal measured.

Average $\mathrm{CO}_{2}$ concentrations during clean marine samples were 388.84 (SD 0.12) and $388.54 \mathrm{ppm}$ (SD 0.8) at Cape Grim and SOAP, respectively, very close to Southern Ocean baseline concentrations in August 2011 (388.51 ppm) and March 2012 (388.69 ppm) (http://www.csiro.au/ greenhouse-gases/). The higher standard deviation from Chatham Rise was due to positive $\mathrm{CO}_{2}$ excursions above background and is therefore likely also a minor impact of ship exhaust.

Finally, the atmospheric radon-222 concentration of $43 \mathrm{mBq} \mathrm{m}^{-3}$ at Cape Grim is indicative of clean marine air. This value compares well to a median baseline sector value of $42 \mathrm{mBq} \mathrm{m}^{-3}$ and is much lower than the median non-baseline value of $378 \mathrm{mBq} \mathrm{m}^{-3}$ reported by Zahorowski et al. (2013).

\subsubsection{Dicarbonyl observations in clean marine air}

The glyoxal mixing ratio at Cape Grim in winter is low (7 $\pm 2 \mathrm{ppt})$ and, in contrast, is higher over Chatham Rise in summer $(23 \pm 8 \mathrm{ppt})$. The low standard deviations indicate consistency in glyoxal mixing ratios in clean marine air at both sites. The higher mixing ratios in summer compared to winter are in agreement with higher VCDs of glyoxal in summer compared to winter over the temperate $\mathrm{SH}$ oceans as observed by SCIAMACHY and GOME-2 (Vrekoussis et al., 2009; Lerot et al., 2010) (see Sect. 3.4 for further discussion of satellite comparison).

In contrast to glyoxal, the methylglyoxal mixing ratios in pristine marine air are higher at Cape Grim $(28 \pm 11 \mathrm{ppt})$ compared to Chatham Rise $(10 \pm 10 \mathrm{ppt})$. The average ratio of glyoxal: methylglyoxal in clean marine air is $\sim 4$ over Chatham Rise (range 1.7-5.9), while at Cape Grim the average ratio is 0.3 (range $0.2-0.4$ ) Given that many of the gas phase precursors of methylglyoxal are also precursors of glyoxal, this major difference in ratios at the two sites is striking and is also seen when taking into account non-pristine marine samples. Possible reasons for this difference are discussed in Sect. 3.2.3 below.

\subsection{Clean marine versus all data and comparison with other marine background observations}

Cape Grim and Chatham Rise dicarbonyl observations from clean marine samples and for all samples are presented in Table 2. For comparison, other studies reporting mixing ratios of glyoxal and methylglyoxal from remote temperate and tropical oceans are also presented. Where other studies have explicitly excluded the possibility of terrestrial influence via back trajectories or other means, these values are listed as "clean marine." Where the possibility of terrestrial influence has not been investigated, values are listed as "all data"; however, values listed under "all data" are not necessarily affected by air of terrestrial origin.

\subsubsection{Glyoxal}

Average mixing ratios of glyoxal at both Cape Grim and Chatham Rise are higher compared to clean marine samples when averaging all samples (which include air from all wind directions and hence terrestrial sources). This is expected as the terrestrial environment is a major source of the important biogenic dicarbonyl precursor gases isoprene and $\alpha$-pinene and is also a source of precursors from anthropogenic and biomass burning sources, including longer-lived 
Table 2. Glyoxal and methylglyoxal compared to dicarbonyl measurements from other remote oceanic sites. Data is listed as being of clean marine origin where the study explicitly excludes terrestrial influence. All concentrations are in ppt. Values are mean \pm SD; SH stands for Southern Hemisphere; NH stands for Northern Hemisphere.

\begin{tabular}{|c|c|c|c|c|c|c|c|c|c|}
\hline & & \multicolumn{4}{|c|}{ Temperate ocean } & \multicolumn{4}{|c|}{ Tropical ocean } \\
\hline & & $\begin{array}{l}\text { Southern } \\
\text { Ocean } \\
\text { (Cape } \\
\text { Grim) } \\
\text { This work }\end{array}$ & $\begin{array}{l}\text { South-west } \\
\text { Pacific } \\
\text { (Chatham } \\
\text { Rise) } \\
\text { This work }\end{array}$ & $\begin{array}{l}\text { South-west } \\
\text { Pacific } \\
\text { (Chatham }^{\text {Rise })^{\mathrm{a}}}\end{array}$ & $\begin{array}{l}\text { North } \\
\text { Pacific and } \\
\text { Atlantic }^{\mathrm{a}}\end{array}$ & $\begin{array}{l}\text { Tropical } \\
\text { Pacific } \\
\text { and Atlantic }\end{array}$ & $\begin{array}{l}\text { Eastern } \\
\text { Tropical } \\
\text { Pacific }^{b}\end{array}$ & $\begin{array}{l}\text { Tropical } \\
\text { Pacific }^{c}\end{array}$ & $\begin{array}{l}\text { Caribbean } \\
\text { and } \\
\text { Sargasso } \\
\text { Sea }^{d}\end{array}$ \\
\hline \multirow[t]{2}{*}{ Glyoxal } & $\begin{array}{l}\text { clean marine } \\
\text { origin }\end{array}$ & $7 \pm 2$ & $23 \pm 8$ & - & - & - & $\begin{array}{l}43 \pm 9(\mathrm{SH}) \\
32 \pm 6(\mathrm{NH})\end{array}$ & $63 \pm 21$ & - \\
\hline & all data & $10 \pm 6$ & $30 \pm 12$ & $23 \pm 10$ & $25 \pm 13$ & $\begin{array}{l}24 \pm 12(\mathrm{SH}) \\
26 \pm 15(\mathrm{NH})\end{array}$ & - & - & 80 \\
\hline \multirow[t]{2}{*}{$\begin{array}{l}\text { Methyl- } \\
\text { glyoxal }\end{array}$} & $\begin{array}{l}\text { clean marine } \\
\text { origin }\end{array}$ & $28 \pm 11$ & $10 \pm 10$ & - & - & - & - & - & - \\
\hline & all data & $57 \pm 32$ & $19 \pm 14$ & - & - & - & - & - & $\sim 10$ \\
\hline
\end{tabular}

${ }^{a}$ Majahan et al. (2014) (only data above MDL has been included in average).

b Coburn et al. (2014).

c Sinreich et al. (2010)

d Zhou and Mopper (1990).

gases such as acetylene, benzene, acetone, alkanes and $>\mathrm{C}_{2}$ alkenes, which can travel long distances before being oxidised. Higher standard deviations in all samples compared to clean marine samples likely reflect a greater variation in concentrations of precursor gases resulting from differing wind directions. Interestingly, at Cape Grim, the average enhancement in glyoxal when including data from all wind direction is only 3 ppt, even though a further 28 samples have been included. This suggests terrestrial sources have a minimal contribution to glyoxal mixing ratios at Cape Grim in winter.

The glyoxal mixing ratio from Cape Grim of $7 \mathrm{ppt}$ in clean marine conditions and $10 \mathrm{ppt}$ in all conditions is the lowest mixing ratio that has been reported over the world's oceans to date. This low mixing ratio is supported in part by the study by Mahajan et al. (2014), in which many of the observations over the temperate $\mathrm{SH}$ oceans were below detection limits. The glyoxal mixing ratio from all Chatham Rise data ( $30 \pm 12 \mathrm{ppt})$ compares well to the mixing ratio derived from MAX-DOAS measurements during the same voyage (23 $\pm 10 \mathrm{ppt})$ (Mahajan et al., 2014). Despite the techniques employing different approaches (in situ derivatised samples versus column measurement), this suggests good agreement between these techniques at these low mixing ratios. Recent intercomparisons of dicarbonyl measurement techniques have examined the relationship between optical and derivatisation techniques, but with a focus on a wider range of mixing ratios than observed over the remote ocean (Thalman et al., 2014; Pang et al., 2014).

The glyoxal mixing ratios from Chatham Rise also compare well to those observed by Mahajan et al. (2014) over the North Pacific and Atlantic (25 \pm 13 ppt) and tropical Pacific and Atlantic ( $24 \pm 12 \mathrm{ppt} \mathrm{SH}, 26 \pm 15 \mathrm{ppt} \mathrm{NH})$. It should be noted that the Mahajan et al. (2014) values were calculated only from data above the instrument detection limit and so contain a positive bias and are upper estimates. Chatham Rise mixing ratios are also similar to the eastern tropical Pacific NH average (32 \pm 6 ppt) (Coburn et al., 2014) but somewhat lower than those observed in the SH eastern tropical Pacific (43 \pm 9 ppt) (Coburn et al., 2014) and over the tropical Pacific $(63 \pm 21 \mathrm{ppt})$ (Sinreich et al., 2010). The Caribbean Sea value of $80 \mathrm{ppt}$ is the highest average mixing ratio reported over the oceans and substantially higher than mixing ratios observed in this study, although the variation of this value is not given (Zhou and Mopper, 1990). Overall, the synthesis of glyoxal observations from this and other studies provides compelling evidence for the widespread presence of glyoxal, in non-negligible mixing ratios, in the atmosphere over the remote oceans.

\subsubsection{Methylglyoxal}

Mixing ratios of methylglyoxal at Cape Grim and Chatham Rise are higher when considering all data and have greater variation, reflecting substantial influence of terrestrial precursors. In particular, mixing ratios of methylglyoxal at Cape Grim in all samples are approximately twice the mixing ratios of clean marine samples. This significant enhancement at Cape Grim in all data is likely due to substantial terrestrial influence at Cape Grim when considering all wind directions. The station is bounded by farmland to the east and southeast, and mainland Australia and the city of Melbourne are $\sim 300 \mathrm{~km}$ north across Bass Straight. The greater enhancement of methylglyoxal compared to glyoxal in all data from Cape Grim may be due to the much higher yield of methylglyoxal from isoprene and monoterpenes compared to gly- 
oxal and the rich source of methylglyoxal precursors from urban regions including alkenes and alkanes $>\mathrm{C}_{2}$ (Fu et al., 2008).

The only other observations of methylglyoxal over the world's oceans come from the Caribbean Sea (Zhou and Mopper, 1990), with an approximate value of $\sim 10 \mathrm{ppt}$, which is somewhat lower than that observed at Cape Grim, but in agreement with Chatham Rise mixing ratios in this study.

\subsubsection{Differences between dicarbonyl ratios at Cape Grim and Chatham Rise}

The average ratio of glyoxal:methylglyoxal is 3.8 over Chatham Rise (range 1.7-5.9) in clean marine air and 2.3 in all samples (range 1.2-5.9). At Cape Grim the average ratio is 0.3 (range $0.2-0.4$ ) in clean marine air and 0.2 in all samples (range 0.1-0.4). The dominance of methylglyoxal at Cape Grim and glyoxal at Chatham Rise points to a major difference between sites and warrants further investigation.

The back trajectories of air in clean marine samples at both Cape Grim and Chatham Rise indicate that the air sampled at both sites originated from the Southern Ocean, from a latitude of $55-65^{\circ} \mathrm{S} 96 \mathrm{~h}$ previously (Fig. 4). A major difference between the back trajectories of the two sites is the longitude, with Cape Grim back trajectories covering $50-140^{\circ} \mathrm{E}$ and the trajectories from the more easterly located Chatham Rise covering $90-175^{\circ} \mathrm{E}$. The 3-D trajectory altitude (not shown) suggests that air from all clean oceanic samples at both sites travelled in the lower $750 \mathrm{~m}$ of the troposphere for $24 \mathrm{~h}$ previously and had originated at a height of between $500-1500 \mathrm{~m}$ (Chatham Rise) and 300-1200 m (Cape Grim) up to $48 \mathrm{~h}$ previously. No clear differences in vertical back trajectories between sites or relationship between height and mixing ratios were evident.

Because glyoxal and methylglyoxal are so short-lived, their observed mixing ratios are due to an equilibrium between local production and loss. Therefore, the difference in ratios between sites indicates a major difference or differences in production or loss rates.

If differences in ratios are due to differing rates of production of dicarbonyls, this could be due to (a) varying concentrations of precursor gases, (b) different emission rates of dicarbonyls from the SML or (c) other unconfirmed production mechanisms. Methylglyoxal and glyoxal have a number of overlapping gas phase precursors, and while there are precursors specific to each (e.g. acetylene, acetone and benzene for glyoxal and higher alkanes and alkenes for methylglyoxal) (Fu et al., 2008), in clean marine conditions precursor mixing ratios are unlikely to differ significantly between sites. The calculated yield of dicarbonyls from parallel or best-estimate precursor mixing ratios at both sites is low (see Sect. 3.3), and so other production mechanisms must be dominating at these sites.
Emission of glyoxal from the SML has only very recently been reported for the first time (Zhou et al., 2014), and there is no evidence as yet of direct emission of methylglyoxal from the oceans. It is likely that methylglyoxal is emitted from the oceans: it has been measured alongside glyoxal in the SML in concentrations which are enhanced above the bulk water, indicating its production in the SML (van Pinxteren and Herrmann, 2013; Zhou and Mopper, 1990). However, the relative abundance of methylglyoxal in the SML compared to glyoxal is highly uncertain, but the studies that have investigated this have found higher concentrations of glyoxal compared to methylglyoxal by a factor of 3 (van Pinxteren and Herrmann, 2013) and 5 (Zhou and Mopper, 1990). Meanwhile, a laboratory study which detected glyoxal from oxidation of the SML did not find evidence for methylglyoxal production (Zhou et al., 2014). It is therefore possible that the ratio of glyoxal : methylglyoxal is higher at Chatham Rise compared to Cape Grim due to enhanced direct emission of glyoxal from biologically productive waters, which were targeted over Chatham Rise, in contrast to Cape Grim, which in winter samples air which has passed over waters of low biological productivity. The likelihood of SML as a major source of glyoxal is uncertain given the modest atmospheric yields of glyoxal in laboratory studies (Zhou et al., 2014) and modest positive fluxes of glyoxal from the tropical ocean (Coburn et al., 2014). However, the emission of dicarbonyls from the temperate oceans has not been studied, and so the temperate SML, as a source of dicarbonyls particularly in biologically active regions such as Chatham Rise, cannot be discounted.

It is also possible that the difference in dicarbonyl ratios between the two sites is due in part to differences in loss rates between glyoxal and methylglyoxal. The major sink for both dicarbonyls is photolysis, which is unlikely to explain the difference in observed ratios. Other sinks include oxidation by $\mathrm{OH}$, irreversible uptake into cloud droplets and particles followed by conversion to SOA, or wet or dry deposition ( $\mathrm{Fu}$ et al., 2008). Satellite imagery shows both sites had partial cloud cover during the sampling periods; however, a major difference was the amount of rainfall that occurred at Cape Grim (90 mm over 33 days) compared to during dicarbonyl sampling over Chatham Rise ( $3 \mathrm{~mm}$ over 6 days). Specifically, during sampling of the Cape Grim clean marine samples, $1-7 \mathrm{~mm}$ of rain fell each day (a total of $14.0 \mathrm{~mm}$ for five samples), while during clean marine Chatham Rise samples, 0-0.4 mm fell each day (a total of $0.57 \mathrm{~mm}$ for two samples). It is possible that due to the higher Henry's law constant of glyoxal compared to methylglyoxal (Kroll et al., 2005; Zhou and Mopper, 1990; Betterton and Hoffmann, 1988), glyoxal was more efficiently removed from the atmosphere via wet deposition at Cape Grim due to its more rapid uptake into aqueous particles. While wet deposition is a globally minor sink, it is likely to be important at night in the absence of other major sinks (Fu et al., 2008). However, the reason for this difference cannot be determined conclusively. The 
only other observations of glyoxal and methyglyoxal over the open ocean for comparison were made in the tropics (Zhou and Mopper, 1990) and show an average glyoxal mixing ratio far in excess of the methylglyoxal mixing ratio. This is in direct contrast to Cape Grim and in partial agreement with the Chatham Rise results. Production and loss processes at each site could be explored with chemical modelling.

\subsection{Calculation of expected glyoxal and methylglyoxal yields from measured VOC precursors in clean marine air}

Expected yields of glyoxal and methylglyoxal were calculated, based, where possible, on parallel precursor VOC measurements over Chatham Rise and Cape Grim (Table 3). Where a concurrent measurement of a precursor was not available, an estimate was made. All estimated precursor mixing ratios are identified, and the source of the estimate is given in Table 3. Where no observations of the precursor at the site were available (e.g. toluene and xylene in winter at Cape Grim) but observations of a similar compound class were available (e.g. benzene), the mixing ratio of benzene was used as a reliable upper estimate for shorter-lived toluene and xylenes. Where no observations of the precursor were available and no measurements of compounds from a similar class were available, mixing ratios were based on the same precursor species at a different site (e.g. summer Cape Grim acetylene, alkene and alkane observations were used for Chatham Rise). In other cases, in situ observations from the site in the same season were used but based on measurements several years earlier (e.g. Cape Grim ethene and propene). Where observations from the specific season were not available, e.g. winter isoprene, acetone and monoterpenes at Cape Grim, a spring or summer value was used, which for isoprene and monoterpenes is likely to be an upper estimate. Three dicarbonyl precursors - glycoaldehyde, methyl butenol and hydroxyacetone - were excluded from the calculation as all are emitted from terrestrial processes (biomass burning and biogenic emission), and all are short-lived and so are unlikely to contribute to dicarbonyl production over the remote ocean.

The expected mixing ratios of dicarbonyls that could be explained by the oxidation of each precursor were calculated according to the following equation:

$\mathrm{MR}_{\text {dicarbonyl }}=\frac{\mathrm{MR}_{\text {precursor }} \times Y_{\text {dicarbonyl }}}{\tau_{\text {precursor }}} \times \tau_{\text {dicarbonyl }}$.

Where $M R_{\text {dicarbonyl }}$ is the mixing ratio of dicarbonyl, $\mathrm{MR}_{\text {precursor }}$ is the mixing ratio of precursor, $\mathrm{Y}_{\text {dicarbonyl }}$ is the yield of dicarbonyl, $\tau_{\text {prec }}$ is the lifetime of precursor and $\tau_{\text {dicarbonyl }}$ is the lifetime of dicarbonyl.

Global annual mean molar yields of glyoxal and methylglyoxal from precursor gases were taken from $\mathrm{Fu}$ et al. (2008). Lifetimes of all precursors were calculated based on average daytime concentrations of $[\mathrm{OH}]$ of $8.7 \times 10^{5}$ molecules $\mathrm{cm}^{-3}$ at Chatham Rise in March and $3.7 \times 10^{5}$ molecules $\mathrm{cm}^{-3}$ at Cape Grim in AugustSeptember, except for monoterpenes (proxy for $\alpha$-pinene), isoprene and propene lifetimes, which were based on the $[\mathrm{OH}]$ stated above and [ozone] of $4.9 \times 10^{11}$ molecules $\mathrm{cm}^{-3}$ at Chatham Rise and $8.0 \times 10^{11}$ molecules $\mathrm{cm}^{-3}$ at Cape Grim (see Sect. 2.2.3). Global average lifetimes of glyoxal $(2.9 \mathrm{~h})$ and methylglyoxal (1.6 h) were used (Fu et al., 2008).

Table 3. shows that the small proportion of glyoxal and methylglyoxal production accounted for is largely driven by isoprene and monoterpenes. The precursors can explain at most 1-3 ppt of glyoxal and methylglyoxal at these two sites, which equates to only $17 \%$ and $10 \%$ of glyoxal and $10 \%$ and $29 \%$ of methylglyoxal over Cape Grim and Chatham Rise, respectively. By dividing the difference between the measured and calculated mixing ratios by the average global lifetime of glyoxal and methylglyoxal, the production rate in the boundary layer required to reconcile the measured and calculated dicarbonyl mixing ratios can be determined. For glyoxal, the additional production rate required is $48 \mathrm{pptday}^{-1}\left(97 \mathrm{pptC} d a y^{-1}\right.$ ) and $172 \mathrm{pptday}^{-1}$ (343 $\mathrm{pt} \mathrm{day}^{-1}$ ), while for methylglyoxal the additional production rate required is $378 \mathrm{ppt} d a y^{-1}\left(1135 \mathrm{pptC}^{-1 a y}{ }^{-1}\right)$ and $106 \mathrm{pptday}^{-1}\left(318 \mathrm{pptC}^{\mathrm{Cay}}{ }^{-1}\right)$ at Cape Grim and Chatham Rise.

As mentioned in Sect. 2.2.3, the isoprene and monoterpene mixing ratios over Chatham Rise were below the instrument detection much of the time, and substitution of half MDLs may result in an upper estimate of mixing ratios for these species. Regardless, this is the first study which has used concurrent measurements of these important precursors to constrain the yields of glyoxal and methylglyoxal. As parallel isoprene and monoterpene mixing ratios were not available at Cape Grim, the yield calculation used summer and spring isoprene and monoterpene mixing ratios which are likely to result in an upper estimate of dicarbonyl mixing ratios resulting from precursor oxidation. Conversely, using the global average lifetimes of glyoxal and methylglyoxal is likely to lead to an underestimate of the mixing ratio of dicarbonyls at Cape Grim as actual dicarbonyl lifetimes in winter at Cape Grim are likely to be longer than the global average. The calculation also does not take into account diurnal variation in production and loss rates. However, Coburn et al. (2014) showed that, while glyoxal over the eastern tropical Pacific varied by approximately $15 \mathrm{ppt}(\sim 30 \%)$ between night and day, it did not decrease below $30 \mathrm{ppt}$ at night (average of both hemispheres). The approach used here should therefore give a good approximation of the $24 \mathrm{~h}$ dicarbonyl mixing ratio expected from the oxidation of precursors. The absence of photolytic destruction and $\mathrm{OH}$ oxidation of dicarbonyls at night (the dominant known sinks), coupled with an absence of dicarbonyl production through $\mathrm{OH}$ oxidation of precursors at night (the dominant known source), likely contributes to the relatively constant mixing ratios between day and night. 
Table 3. Calculated dicarbonyl yields based on precursor data from Cape Grim and Chatham Rise. Yields and dicarbonyl lifetimes based on Fu et al. (2008).

\begin{tabular}{|c|c|c|c|c|c|c|}
\hline \multirow[t]{2}{*}{ Precursor } & \multicolumn{2}{|c|}{ Precursor mixing ratios (ppt) } & \multicolumn{2}{|c|}{ Glyoxal yield (ppt) } & \multicolumn{2}{|c|}{ Methylglyoxal yield (ppt) } \\
\hline & Chatham Rise & Cape Grim & Chatham Rise & Cape Grim & Chatham Rise & Cape Grim \\
\hline Acetylene & $3^{\mathrm{a}}$ & $39^{\mathrm{a}}$ & 0.02 & 0.08 & $\mathrm{n} / \mathrm{a}$ & $\mathrm{n} / \mathrm{a}$ \\
\hline Ethene & $51^{\mathrm{b}}$ & $31^{\mathrm{b}}$ & 0.22 & 0.06 & $\mathrm{n} / \mathrm{a}$ & $\mathrm{n} / \mathrm{a}$ \\
\hline Propene & $17^{\mathrm{b}}$ & $8^{\mathrm{b}}$ & $\mathrm{n} / \mathrm{a}$ & $\mathrm{n} / \mathrm{a}$ & 0.04 & 0.03 \\
\hline Propane & $33^{\mathrm{c}}$ & $35^{\mathrm{c}}$ & $\mathrm{n} / \mathrm{a}$ & $\mathrm{n} / \mathrm{a}$ & 0.02 & 0.02 \\
\hline Alkanes $>C_{3}^{\mathrm{f}}$ & 54 & $52^{\mathrm{c}}$ & $\mathrm{n} / \mathrm{a}$ & $\mathrm{n} / \mathrm{a}$ & 0.02 & 0.02 \\
\hline Isoprene & 14 & $14^{\mathrm{d}}$ & 0.85 & 0.43 & 1.89 & 1.97 \\
\hline Benzene & 8 & $9^{\mathrm{a}}$ & 0.02 & 0.01 & $\mathrm{n} / \mathrm{a}$ & $\mathrm{n} / \mathrm{a}$ \\
\hline Toluene & 9 & $9^{g}$ & 0.08 & 0.03 & 0.03 & 0.03 \\
\hline Xylenes sum & 10 & $9 \mathrm{~g}$ & 0.27 & 0.10 & 0.22 & 0.19 \\
\hline Monoterpenes & 32 & $17^{\mathrm{e}}$ & 0.83 & 0.44 & 0.69 & 0.48 \\
\hline Acetone & 89 & $118^{\mathrm{d}}$ & $\mathrm{n} / \mathrm{a}$ & $\mathrm{n} / \mathrm{a}$ & 0.01 & 0.02 \\
\hline Sum yield (ppt) & & & 2.3 & 1.2 & 2.9 & 2.8 \\
\hline$\%$ Explained & & & 10 & 17 & 29 & 10 \\
\hline $\begin{array}{l}\text { Where supplementary ( } \\
\text { a Cape Grim flasks (NC } \\
{ }^{b} \text { Kivlighon (2001). } \\
{ }^{c} \text { Cape Grim flasks (IN } \\
{ }^{d} \text { Galbally et al. (2007) } \\
{ }^{\mathrm{e}} \text { Lawson et al. (2011) } \\
{ }^{\mathrm{f}} \text { Sum of } \mathrm{C}_{4} \text { and } \mathrm{C}_{5} \text {. } \\
{ }^{\mathrm{g}} \text { Upper estimate based }\end{array}$ & $\begin{array}{l}\text { g. non-parallel) mea } \\
\text { AA HATS analysis). } \\
\text { TAAR analysis). } \\
\text { upper estimate Cape } \\
\text { ape Grim baseline s } \\
\text { n benzene. }\end{array}$ & $\begin{array}{l}\text { Im summer). } \\
\text { g data, see text }\end{array}$ & xplanation). & ollows: & & \\
\hline
\end{tabular}

The low proportion of dicarbonyl mixing ratios that can be explained by the oxidation of precursors calculated here supports previous claims that there are unlikely to be sufficient levels of VOC precursors over the remote oceans to explain the non-negligible levels of glyoxal observed (Coburn et al., 2014; Sinreich et al., 2010). For the first time, we show that the same applies to methylglyoxal over the ocean.

The large proportion of glyoxal and methylglyoxal which cannot be explained by the precursor mixing ratios confirms the importance of other production mechanisms. As discussed previously, it is unclear whether positive SML fluxes are sufficiently large to explain the unaccounted for portion of these gases at Cape Grim and Chatham Rise. Kwan et al. (2006) estimated that $\mathrm{OH}$ oxidation of organic aerosol (OA) may result in a production rate of up to $70 \mathrm{ppt} \mathrm{C}$ day $^{-1}$ of Oxygenated volatile organic compounds (OVOCs) in the FT and a production rate of up to $\sim 500 \mathrm{ppt} \mathrm{Cday}^{-1}$ OVOCs in the lower continental troposphere in the summertime. The combined boundary layer production rate of glyoxal and methylglyoxal at Chatham Rise needed to reconcile the measured and calculated mixing ratios is $661 \mathrm{pptC}^{\mathrm{C}} \mathrm{day}^{-1}$, in reasonable agreement with the Kwan et al. (2006) estimate, while the Cape Grim glyoxal and methylglyoxal flux $\left(1232 \mathrm{ppt} \mathrm{C} \mathrm{day}^{-1}\right)$ is a factor of $2-3$ times higher. Whilst the Kwan et al. (2006) estimates contained significant uncertainties and used continental measurements, they do suggest that oxidation of OA may make a non-negligible contribution to the dicarbonyl mixing ratios.
Another possible production mechanism is the oxidation of as yet unidentified gas phase precursors.

\subsection{Comparison of glyoxal surface observations with satellite vertical columns}

In situ glyoxal mixing ratios from Cape Grim and Chatham Rise were converted into vertical column densities (VCDs) and compared with glyoxal VCDs from GOME-2 on Metop-A.

Mixing ratios were converted to VCDs, assuming that all glyoxal observed was well mixed within the boundary layer and assuming standard conditions of temperature $\left(25^{\circ} \mathrm{C}\right)$ and pressure $(1 \mathrm{~atm})$ throughout the boundary layer. Boundary layer heights of $850 \mathrm{~m}$ were used for both Chatham Rise (average of daytime and nocturnal radiosonde flights) and an average modelled value for Cape Grim in all wind directions (unpublished data; see Zahorowski et al., 2013 for model details). Chatham Rise surface observations were compared to an average GOME-2 column for March 2012 in the region $40-50^{\circ} \mathrm{S}$ and $170-180^{\circ} \mathrm{E}$, while Cape Grim surface observations were compared to GOME-2 columns taken from August-September 2011 in the region $39-42^{\circ} \mathrm{S}$ and $143-$ $147^{\circ} \mathrm{E}$.

In the austral summer, GOME-2 glyoxal columns over the temperate oceans in the $\mathrm{SH}$ are low but somewhat higher than in other remote regions, while in winter the columns are among the lowest observed globally (Lerot et al., 2010). There is low interannual variability in the GOME-2 glyoxal 


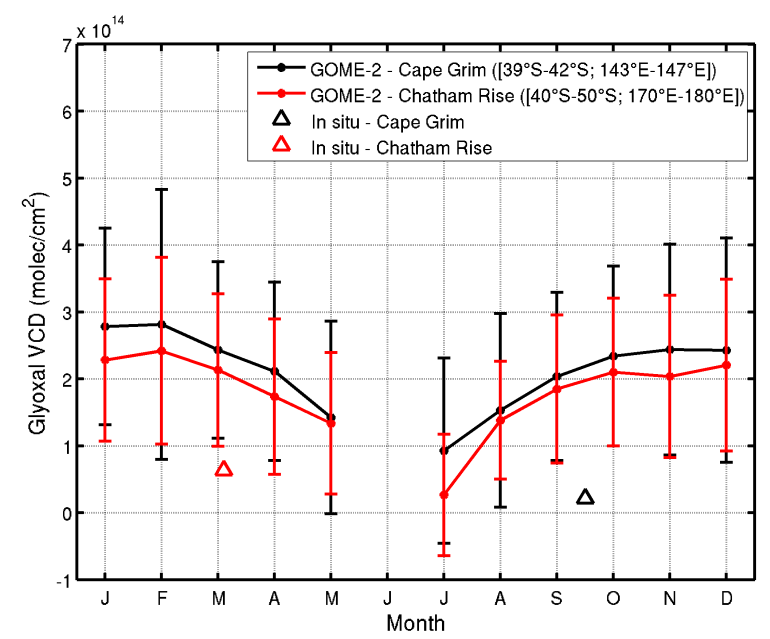

Figure 5. Seasonal glyoxal VCDs retrieved from GOME-2 and calculated from surface-based observations at Cape Grim and Chatham Rise. GOME-2 values are for all data averaged between 2007 and 2012, for regions encompassing Cape Grim and Chatham Rise. Error bars for surface-based VCDs are insignificant on this scale and are not shown (see text for details).

VCDs in both the regions encompassing Cape Grim and Chatham Rise but a clear seasonal cycle, with a maximum VCD in the summer months (December-February) and a minimum in the autumn-winter months (May-August). The 2007-2012 average seasonal variability of GOME-2 glyoxal VCDs from the sites above is shown in Fig. 5. In June, VCDs cannot be calculated due to insufficient satellite sensitivity, resulting from observation geometry (low angle of the sun).

Cape Grim VCDs calculated from in situ observations are $2.1 \times 10^{13}$ molecules $\mathrm{cm}^{-2}$ (standard error of mean $2.1 \times 10^{12}$ ), while Chatham Rise calculated VCDs are $6.3 \times 10^{13}$ molecules $\mathrm{cm}^{-2}$ (standard error of mean $\left.1.0 \times 10^{13}\right)$. In comparison, satellite-retrieved VCDs are $1.8 \times 10^{14}$ molecules $\mathrm{cm}^{-2}$ for the Cape Grim region and $2.4 \times 10^{14}$ molecules $\mathrm{cm}^{-2}$ for the Chatham Rise region (both with an uncertainty of $\pm 1.3 \times 10^{14}$ molecules $\mathrm{cm}^{-2}$ ) (Fig. 5). While both satellite columns and in situ columns observe higher VCD over Chatham Rise in summer than Cape Grim in winter, the satellite VCDs exceed in situ VCDs at both sites by $>1.5 \times 10^{14}$ molecules $\mathrm{cm}^{-2}$. There are several possible factors that may be contributing to the higher satellite VCD. The first may be due to the assumption that all of the glyoxal observed by the satellites is in the boundary layer. Aircraft measurements made as part of the TORERO campaign (Tropical Ocean Troposphere Exchange of Reactive Halogens and OVOCs) have confirmed the widespread presence of glyoxal in the free troposphere (Volkamer, 2014). If glyoxal is also present in the free troposphere over the temperate SH oceans, the satellite, which is sensitive to the entire troposphere, would indeed observe glyoxal VCD larger than VCD calculated from in situ measurements, which represent only the boundary layer. If glyoxal is widespread in the free troposphere, this clearly has important implications for the interpretation of satellite column data. Another reason may be due to the significant challenges in retrieving low VCDs of glyoxal over the oceans, due to interferences by liquid water absorption, discussed elsewhere (Vrekoussis et al., 2009; Lerot et al., 2010). Also, the satellite glyoxal retrieval algorithm includes a normalisation procedure comparing actual retrieved columns to a reference value taken in a reference sector. As discussed in Miller et al. (2014), this reference value might be too large. Another possible reason is that the satellite VCDs are measured only once per day, during the satellite overpass at 9:45am, whereas the in situ observations reported here are 24-hour averages. If there is a diurnal variation in glyoxal mixing ratios at these sites, as was shown over the tropical Pacific Ocean (Coburn et al., 2014), the satellite VCD may not be representative of the 24-hour average.

Difficulty reconciling satellite VCDs and in situ observations over the ocean has recently been noted elsewhere, including the tendency of satellite VCDs to exceed in situ measurements, particularly in regions with low VCDs which are at the limits of satellite sensitivity (Coburn et al., 2014; Mahajan et al., 2014). Further comparisons between in situ and satellite observations over the oceans are needed, including characterisation of the vertical distribution of glyoxal.

\section{Conclusions}

This work confirms the presence of short-lived dicarbonyl glyoxal over the remote temperate oceans, even in winter in very pristine air over biologically unproductive waters. We provide the first observations of methylglyoxal over temperate oceans and confirm its presence alongside glyoxal. These observations support the likely widespread contribution from these dicarbonyls to SOA formation over the ocean.

Glyoxal mixing ratios at Cape Grim in winter are the lowest measured over the ocean, while glyoxal at Chatham Rise is similar to other temperate mixing ratios and similar to or at the lower end of tropical observations. Methylglyoxal observations at Cape Grim and Chatham Rise are comparable to the only other observations available (tropical Northern Hemisphere ocean).

Chatham Rise glyoxal observations from this study agree well with observations made via MAX-DOAS on the same voyage, suggesting a good agreement between the technique used in this work (DNPH derivatisation with HPLC analysis optimised for dicarbonyl detection) and the optical technique.

Different ratios of glyoxal : methylglyoxal were observed at the two locations, with an average ratio in clean marine air of $\sim 4$ over Chatham Rise (range 1.7-5.9) and 0.3 at Cape Grim (range 0.2-0.4). The reasons for this are unexplained but may be due to a larger positive flux of glyoxal from biologically active waters over Chatham Rise and/or to preferen- 
tial loss of glyoxal over methylglyoxal by wet deposition at Cape Grim. Chemical modelling is suggested to better constrain the production and loss mechanisms.

Expected yields of glyoxal and methylglyoxal were calculated based on parallel measurements of precursor VOCs, including isoprene and monoterpenes. At most, 1-3 ppt of the glyoxal and methylglyoxal observed in clean marine air can be explained from the oxidation of these precursors, confirming a significant contribution from another source over the ocean. While the SML has recently been confirmed as a direct source of glyoxal both in the field and in laboratory studies, it seems unlikely that this positive flux is sufficiently large to explain the atmospheric concentrations observed. Other possible but unconfirmed sources may include the oxidation of as yet unidentified gas precursors or atmospheric oxidation of organic aerosol.

Glyoxal observations were converted to VCDs and compared with GOME-2 satellite VCDs. While in situ and satellite observations both observe a higher glyoxal VCD in summer, the satellite VCD exceeds the surface observations by more than $1.5 \times 10^{14}$ molecules $\mathrm{cm}^{-2}$. Recent observations of glyoxal in the free troposphere suggest that this discrepancy is least in part due to the incorrect assumption that all glyoxal observed over the ocean by satellites is in the MBL. Other reasons for the discrepancy may be due to challenges in retrieving low VCDs of glyoxal over the oceans, including accounting for interference by liquid water absorption and the selection of an appropriate normalisation reference value in the retrieval algorithm. Further comparisons are needed, including the characterisation of the vertical distribution of glyoxal.

Acknowledgements. We thank Rob Gillett and Min Cheng (CSIRO), Nigel Somerville, Jeremy Ward and Sam Cleland (Cape Grim BAPS), and Nick Talbot (NIWA) for assistance with sampling and analysis and James Harnwell (CSIRO) for the design and construction of the sequencer sampling unit. We thank Cliff Law for excellent leadership during the SOAP voyage and the officers and crew of the RV Tangaroa and NIWA Vessels for logistics support.

Radon data and boundary layer heights are courtesy of Alastair Williams, Scott Chambers and Alan Griffiths (ANSTO); carbon dioxide Cape Grim data are courtesy of Paul Krummel and Paul Steele, CSIRO and CGBAPS. Benzene and acetylene data from GCMS analysis of NOAA HATS flasks were collected at Cape Grim courtesy of Steve Montzka (NOAA). OH concentration data from Cape Grim were provided by Stephen Wilson (University of Wollongong). Chatham Rise carbon dioxide data were provided by John McGregor (NIWA), and chlorophyll $a$ data were provided by Cliff Law (NIWA).

Sarah Lawson would like to acknowledge the NIWA Visiting Scientist Scheme and CSIRO's Capability Development Fund for providing financial support for her participation in the SOAP voyage.

Edited by: P. Quinn

\section{References}

Ayers, G. P. and Gras, J. L.: Seasonal relationship between cloud condensation nuclei and aerosol methanesulfonate in marine air, Nature, 353, 834-835, 1991.

Bates, T. S., Quinn, P. K., Frossard, A. A., Russell, L. M., Hakala, J., Petäjä, T., Kulmala, M., Covert, D. S., Cappa, C. D., Li, S. M., Hayden, K. L., Nuaaman, I., McLaren, R., Massoli, P., Canagaratna, M. R., Onasch, T. B., Sueper, D., Worsnop, D. R., and Keene, W. C.: Measurements of ocean derived aerosol off the coast of California, J. Geophys. Res.-Atmos., 117, D00V15, doi:10.1029/2012JD017588, 2012.

Betterton, E. A. and Hoffmann, M. R.: Henry's law constants of some environmentally important aldehydes, Environ. Sci. Technol., 22, 1415-1418, doi:10.1021/es00177a004, 1988.

Bikkina, S., Kawamura, K., Miyazaki, Y., and Fu, P.: High abundances of oxalic, azelaic, and glyoxylic acids and methylglyoxal in the open ocean with high biological activity: implication for secondary OA formation from isoprene, Geophys. Res. Lett., 41, 2014GL059913, doi:10.1002/2014GL059913, 2014.

Bowie, A. R., Brian Griffiths, F., Dehairs, F., and Trull, T. W.: Oceanography of the subantarctic and Polar Frontal Zones south of Australia during summer: setting for the SAZ-Sense study, Deep-Sea Res. Pt. II, 58, 2059-2070, doi:10.1016/j.dsr2.2011.05.033, 2011.

Carslaw, K. S., Lee, L. A., Reddington, C. L., Pringle, K. J., Rap, A., Forster, P. M., Mann, G. W., Spracklen, D. V., Woodhouse, M. T., Regayre, L. A., and Pierce, J. R.: Large contribution of natural aerosols to uncertainty in indirect forcing, Nature, 503, 67-71, doi:10.1038/nature12674, 2013.

Claeys, M., Wang, W., Vermeylen, R., Kourtchev, I., Chi, X. G., Farhat, Y., Surratt, J. D., Gomez-Gonzalez, Y., Sciare, J., and Maenhaut, W.: Chemical characterisation of marine aerosol at Amsterdam Island during the austral summer of 2006-2007, J. Aerosol. Sci., 41, 13-22, doi:10.1016/j.jaerosci.2009.08.003, 2010.

Coburn, S., Ortega, I., Thalman, R., Blomquist, B., Fairall, C. W., and Volkamer, R.: Measurements of diurnal variations and Eddy Covariance (EC) fluxes of glyoxal in the tropical marine boundary layer: description of the Fast LED-CE-DOAS instrument, Atmos. Meas. Tech. Discuss., 7, 6245-6285, doi:10.5194/amtd-76245-2014, 2014.

Decesari, S., Finessi, E., Rinaldi, M., Paglione, M., Fuzzi, S., Stephanou, E. G., Tziaras, T., Spyros, A., Ceburnis, D., O'Dowd, C., Dall'Osto, M., Harrison, R. M., Allan, J., Coe, H., and Facchini, M. C.: Primary and secondary marine organic aerosols over the North Atlantic Ocean during the MAP experiment, J. Geophys. Res.-Atmos., 116, D22210, doi:10.1029/2011jd016204, 2011.

Donahue, N. M., Robinson, A. L., Trump, E. R., Riipinen, I., and Kroll, J. H.: Volatility and aging of atmospheric organic aerosol, in: Atmospheric and Aerosol Chemistry, edited by: McNeill, V. F. and Ariya, P. A., Topics in Current Chemistry, Springer-Verlag, Berlin Heidelberg, 97-143, 2014.

Ervens, B., Turpin, B. J., and Weber, R. J.: Secondary organic aerosol formation in cloud droplets and aqueous particles (aqSOA): a review of laboratory, field and model studies, Atmos. Chem. Phys., 11, 11069-11102, doi:10.5194/acp-1111069-2011, 2011. 
Facchini, M. C., Decesari, S., Rinaldi, M., Carbone, C., Finessi, E., Mircea, M., Fuzzi, S., Moretti, F., Tagliavini, E., Ceburnis, D., and O'Dowd, C. D.: Important source of marine secondary organic aerosol from biogenic amines, Environ. Sci. Technol., 42, 9116-9121, doi:10.1021/es8018385, 2008a.

Facchini, M. C., Rinaldi, M., Decesari, S., Carbone, C., Finessi, E., Mircea, M., Fuzzi, S., Ceburnis, D., Flanagan, R., Nilsson, E. D., de Leeuw, G., Martino, M., Woeltjen, J., and O’Dowd, C. D.: Primary submicron marine aerosol dominated by insoluble organic colloids and aggregates, Geophys. Res. Lett., 35, L17814, doi:10.1029/2008GL034210, 2008b.

Fu, P. Q., Kawamura, K., and Miura, K.: Molecular characterization of marine organic aerosols collected during a roundthe-world cruise, J. Geophys. Res.-Atmos., 116, D13302, doi:10.1029/2011jd015604, 2011.

Fu, P. Q., Kawamura, K., Chen, J., Charrière, B., and Sempéré, R.: Organic molecular composition of marine aerosols over the Arctic Ocean in summer: contributions of primary emission and secondary aerosol formation, Biogeosciences, 10, 653-667, doi:10.5194/bg-10-653-2013, 2013.

Fu, T. M., Jacob, D. J., Wittrock, F., Burrows, J. P., Vrekoussis, M., and Henze, D. K.: Global budgets of atmospheric glyoxal and methylglyoxal, and implications for formation of secondary organic aerosols, J. Geophys. Res.-Atmos., 113, D15303, doi:10.1029/2007jd009505, 2008.

Galbally, I. E., Lawson, S. J., Weeks, I. A., Bentley, S. T., Gillett, R. W., Meyer, M., and Goldstein, A. H.: Volatile organic compounds in marine air at Cape Grim, Australia, Environ. Chem., 4, 178-182, doi:10.1071/en07024, 2007.

Gras, J. L.: Postfrontal nanoparticles at Cape Grim: impact on cloud nuclei concentrations, Environ. Chem., 6, 515-523, doi:10.1071/en09076, 2009.

Gras, J. L.: Particles Program Report, Baseline Atmospheric Program (Australia) 2009-2010, edited by: Derek, N., Krummel, P. B., and Cleland, S. J., Australian Bureau of Meteorology and CSIRO Marine and Atmospheric Research, Melbourne, 7375, available at: http://www.bom.gov.au/inside/cgbaps/baseline/ Baseline_2009-2010.pdf, 2014.

Grutter, M., Flores, E., Andraca-Ayala, G., and Báez, A.: Formaldehyde levels in downtown Mexico City during 2003, Atmos. Environ., 39, 1027-1034, doi:10.1016/j.atmosenv.2004.10.031, 2005.

Helmig, D., Bottenheim, J., Galbally, I. E., Lewis, A., Milton, M. J. T., Penkett, S., Plass-Duelmer, C., Reimann, S., Tans, P., and Thiel, S.: Volatile organic compounds in the global atmosphere, EOS T. Am. Geophys. Un., 90, 513-514, doi:10.1029/2009EO520001, 2009.

Helmig, D., Petrenko, V., Martinerie, P., Witrant, E., Röckmann, T., Zuiderweg, A., Holzinger, R., Hueber, J., Thompson, C., White, J. W. C., Sturges, W., Baker, A., Blunier, T., Etheridge, D., Rubino, M., and Tans, P.: Reconstruction of Northern Hemisphere 1950-2010 atmospheric non-methane hydrocarbons, Atmos. Chem. Phys., 14, 1463-1483, doi:10.5194/acp-141463-2014, 2014.

ISO: ISO 6879: Air Quality, Performance Characteristics and Related Concepts for Air Quality Measuring Methods, International Organisation for Standardisation, Geneva, Switzerland, 1995.

Kampf, C. J., Waxman, E. M., Slowik, J. G., Dommen, J., Pfaffenberger, L., Praplan, A. P., Prevot, A. S. H., Baltensperger, U., Hoffmann, T., and Volkamer, R.: Effective
Henry's Law partitioning and the salting constant of glyoxal in aerosols containing sulfate, Environ. Sci. Technol., 47, 42364244, doi:10.1021/es400083d, 2013.

Keywood, M. D.: Aerosol composition at Cape Grim : an evaluation of $\mathrm{PM}_{10}$ sampling program and baseline event switches, in: Baseline Atmospheric Program Australia 2005-2006, edited by: Cainey, J. M., Derek, N., and Krummel, P. B., Australian Bureau of Meteorology and CSIRO Marine and Atmospheric Research, Melbourne, 31-36, available at: http://www.bom.gov.au/inside/ cgbaps/baseline/Baseline_2005-2006.pdf, 2007.

Kivlighon, L. M.: Tropospheric non-methane hydrocarbons at Cape Grim, Masters Thesis, Department of Chemistry, La Trobe University, Melbourne, Australia, 2001.

Korhonen, H., Carslaw, K. S., Spracklen, D. V., Mann, G. W., and Woodhouse, M. T.: Influence of oceanic dimethyl sulfide emissions on cloud condensation nuclei concentrations and seasonality over the remote Southern Hemisphere oceans: a global model study, J. Geophys. Res.-Atmos., 113, D15204, doi:10.1029/2007jd009718, 2008.

Kroll, J. H., Ng, N. L., Murphy, S. M., Varutbangkul, V., Flagan, R. C., and Seinfeld, J. H.: Chamber studies of secondary organic aerosol growth by reactive uptake of simple carbonyl compounds, J. Geophys. Res.-Atmos., 110, D23207, doi:10.1029/2005jd006004, 2005.

Kwan, A. J., Crounse, J. D., Clarke, A. D., Shinozuka, Y., Anderson, B. E., Crawford, J. H., Avery, M. A., McNaughton, C. S., Brune, W. H., Singh, H. B., and Wennberg, P. O.: On the flux of oxygenated volatile organic compounds from organic aerosol oxidation, Geophys. Res. Lett., 33, doi:10.1029/2006g1026144, 2006.

Lana, A., Simó, R., Vallina, S. M., and Dachs, J.: Potential for a biogenic influence on cloud microphysics over the ocean: a correlation study with satellite-derived data, Atmos. Chem. Phys., 12, 7977-7993, doi:10.5194/acp-12-7977-2012, 2012.

Landwehr, S., Miller, S. D., Smith, M. J., Saltzman, E. S., and Ward, B.: Analysis of the PKT correction for direct $\mathrm{CO}_{2}$ flux measurements over the ocean, Atmos. Chem. Phys., 14, 33613372, doi:10.5194/acp-14-3361-2014, 2014.

Lawson, S. J., Galbally, I. E., Gras, J. L., and Dunne, E.: Measurement of VOCs in Marine Air at Cape Grim using PTR-MS, Baseline Atmospheric Program 2007-2008, edited by: Derek, N., and Krummel, P. B., Australian Bureau of Meteorology and CSIRO Marine and Atmospheric Research, Melbourne, available at: http://www.bom.gov.au/inside/cgbaps/ baseline/Baseline_2007-2008.pdf (last access: 22 August 2014), 2011.

Lee, A. K. Y., Herckes, P., Leaitch, W. R., Macdonald, A. M., and Abbatt, J. P. D.: Aqueous $\mathrm{OH}$ oxidation of ambient organic aerosol and cloud water organics: formation of highly oxidized products, Geophys. Res. Lett., 38, L11805, doi:10.1029/2011g1047439, 2011.

Lerot, C., Stavrakou, T., De Smedt, I., Müller, J.-F., and Van Roozendael, M.: Glyoxal vertical columns from GOME-2 backscattered light measurements and comparisons with a global model, Atmos. Chem. Phys., 10, 12059-12072, doi:10.5194/acp10-12059-2010, 2010.

Lim, Y. B., Tan, Y., and Turpin, B. J.: Chemical insights, explicit chemistry, and yields of secondary organic aerosol from $\mathrm{OH}$ radical oxidation of methylglyoxal and glyoxal in the aqueous phase, 
Atmos. Chem. Phys., 13, 8651-8667, doi:10.5194/acp-13-86512013, 2013.

Mahajan, A. S., Prados-Roman, C., Hay, T. D., Lampel, J., Pöhler, D., Großmann, K., Tschritter, J., Frieß, U., Platt, U., Johnston, P., Kreher, K., Wittrock, F., Burrows, J. P., Plane, J. M. C., and Saiz-Lopez, A.: Glyoxal observations in the global marine boundary layer, J. Geophys. Res.-Atmos., 119, 2013JD021388, doi:10.1002/2013JD021388, 2014.

Meskhidze, N. and Nenes, A.: Phytoplankton and cloudiness in the Southern Ocean, Science, 314, 1419-1423, doi:10.1126/science.1131779, 2006.

Meskhidze, N., Xu, J., Gantt, B., Zhang, Y., Nenes, A., Ghan, S. J., Liu, X., Easter, R., and Zaveri, R.: Global distribution and climate forcing of marine organic aerosol: 1. Model improvements and evaluation, Atmos. Chem. Phys., 11, 11689-11705, doi:10.5194/acp-11-11689-2011, 2011.

Miller, C. C., Abad, G. G., Wang, H., Liu, X., Kurosu, T., Jacob, D. J., and Chance, K.: Glyoxal retrieval from the Ozone Monitoring Instrument, Atmos. Meas. Tech. Discuss., 7, 60656112, doi:10.5194/amtd-7-6065-2014, 2014.

Molloy, S. B. and Galbally, I. E.: Analysis and identification of a suitable Baseline definition for tropospheric ozone at Cape Grim, Tasmania, Baseline Atmospheric Program (Australia) 2009-2010, edited by: Derek, N., Krummel, P. B., and Cleland, S. J., Australian Bureau of Meteorology and CSIRO Marine and Atmospheric Research, Melbourne, 716, available at: http://www.bom.gov.au/inside/cgbaps/baseline/ Baseline_2009-2010.pdf, last access: 22 August 2014.

Montzka, S. A., Siso, C., Mondeel, D., Miller, B. R., Hall, B., Elkins, J. W., and Butler, J. H.: Flask Measurements at Cape Grim Baseline Air Pollution Station by the HATS group of NOAA/ESRL/GMD, Baseline Atmospheric Program (Australia) 2009-2010, edited by: Derek, N., Krummel, P. B., and Cleland, S. J., Australian Bureau of Meteorology and CSIRO Marine and Atmospheric Research, Melbourne, 5155, available at: http://www.bom.gov.au/inside/cgbaps/baseline/ Baseline_2009-2010.pdf, last access: 22 August 2014.

Müller, K., Lehmann, S., van Pinxteren, D., Gnauk, T., Niedermeier, N., Wiedensohler, A., and Herrmann, H.: Particle characterization at the Cape Verde atmospheric observatory during the 2007 RHaMBLe intensive, Atmos. Chem. Phys., 10, 2709-2721, doi:10.5194/acp-10-2709-2010, 2010.

Myriokefalitakis, S., Vrekoussis, M., Tsigaridis, K., Wittrock, F., Richter, A., Brühl, C., Volkamer, R., Burrows, J. P., and Kanakidou, M.: The influence of natural and anthropogenic secondary sources on the glyoxal global distribution, Atmos. Chem. Phys., 8, 4965-4981, doi:10.5194/acp-8-4965-2008, 2008.

O'Dowd, C. D., Facchini, M. C., Cavalli, F., Ceburnis, D., Mircea, M., Decesari, S., Fuzzi, S., Yoon, Y. J., and Putaud, J. P.: Biogenically driven organic contribution to marine aerosol, Nature, 431, 676-680, doi:10.1038/nature02959, 2004.

Olsen, R., Thorud, S., Hersson, M., Ovrebo, S., Lundanes, E., Greibrokk, T., Ellingsen, D. G., Thomassen, Y., and Molander, P.: Determination of the dialdehyde glyoxal in workroom air-development of personal sampling methodology, J. Environ. Monitor., 9, 687-694, doi:10.1039/B700105N, 2007.

Orellana, M. V., Matrai, P. A., Leck, C., Rauschenberg, C. D., Lee, A. M., and Coz, E.: Marine microgels as a source of cloud condensation nuclei in the high Arctic, P. Natl. Acad. Sci. USA 108, 13612-13617, doi:10.1073/pnas.1102457108, 2011.

Ovadnevaite, J., Ceburnis, D., Martucci, G., Bialek, J., Monahan, C., Rinaldi, M., Facchini, M. C., Berresheim, H., Worsnop, D. R., and O'Dowd, C.: Primary marine organic aerosol: a dichotomy of low hygroscopicity and high CCN activity, Geophys. Res. Lett., 38, L21806, doi:10.1029/2011g1048869, 2011a.

Ovadnevaite, J., O'Dowd, C., Dall'Osto, M., Ceburnis, D., Worsnop, D. R., and Berresheim, H.: Detecting high contributions of primary organic matter to marine aerosol: a case study, Geophys. Res. Lett., 38, L02807, doi:10.1029/2010gl046083, $2011 b$.

Pétron, G., Frost, G., Miller, B. R., Hirsch, A. I., Montzka, S. A., Karion, A., Trainer, M., Sweeney, C., Andrews, A. E., Miller, L., Kofler, J., Bar-Ilan, A., Dlugokencky, E. J., Patrick, L., Moore, C. T., Ryerson, T. B., Siso, C., Kolodzey, W., Lang, P. M., Conway, T., Novelli, P., Masarie, K., Hall, B., Guenther, D., Kitzis, D., Miller, J., Welsh, D., Wolfe, D., Neff, W., and Tans, P.: Hydrocarbon emissions characterization in the Colorado Front Range: a pilot study, J. Geophys. Res.-Atmos., 117, D04304, doi:10.1029/2011JD016360, 2012.

Rhoderick, G. C., Duewer, D. L., Apel, E., Baldan, A., Hall, B., Harling, A., Helmig, D., Heo, G. S., Hueber, J., Kim, M. E., Kim, Y. D., Miller, B., Montzka, S., and Riemer, D.: International comparison of a hydrocarbon gas standard at the picomol per mol level, Anal. Chem., 86, 2580-2589, doi:10.1021/ac403761u, 2014.

Rinaldi, M., Decesari, S., Finessi, E., Giulianelli, L., Carbone, C., Fuzzi, S., O’Dowd, C., Ceburnis, D., and Facchini, M. C.: Primary and secondary organic marine aerosol and oceanic biological activity: recent results and new perspectives for future studies, Advances in Meteorology, 2010, 310682, doi:10.1155/2010/310682, 2010

Rinaldi, M., Decesari, S., Carbone, C., Finessi, E., Fuzzi, S., Ceburnis, D., O'Dowd, C. D., Sciare, J., Burrows, J. P., Vrekoussis, M., Ervens, B., Tsigaridis, K., and Facchini, M. C.: Evidence of a natural marine source of oxalic acid and a possible link to glyoxal, J. Geophys. Res.-Atmos., 116, D16204, doi:10.1029/2011jd015659, 2011.

Schauer, J. J., Kleeman, M. J., Cass, G. R., and Simoneit, B. R. T. Measurement of emissions from air pollution sources. 2. C1 through C30 organic compounds from medium duty diesel trucks, Environ. Sci. Technol., 33, 1578-1587, doi:10.1021/es980081n, 1999.

Sciare, J., Favez, O., Sarda-Esteve, R., Oikonomou, K., Cachier, H., and Kazan, V.: Long-term observations of carbonaceous aerosols in the Austral Ocean atmosphere: evidence of a biogenic marine organic source, J. Geophys. Res.-Atmos., 114, D15302, doi:10.1029/2009jd011998, 2009.

Sedehi, N., Takano, H., Blasic, V. A., Sullivan, K. A., and De Haan, D. O.: Temperature- and pH-dependent aqueous-phase kinetics of the reactions of glyoxal and methylglyoxal with atmospheric amines and ammonium sulfate, Atmos. Environ., 77, 656-663, doi:10.1016/j.atmosenv.2013.05.070, 2013.

Shaw, S., Gantt, B., and Meskhidze, N.: Production and emission of marine isoprene and monoterpenes: a review, Advances in Meteorology, 2010, 408696, doi:10.1155/2010/408696, 2010. 
Sinreich, R., Volkamer, R., Filsinger, F., Frieß, U., Kern, C., Platt, U., Sebastián, O., and Wagner, T.: MAX-DOAS detection of glyoxal during ICARTT 2004, Atmos. Chem. Phys., 7, 12931303, doi:10.5194/acp-7-1293-2007, 2007.

Sinreich, R., Coburn, S., Dix, B., and Volkamer, R.: Ship-based detection of glyoxal over the remote tropical Pacific Ocean, Atmos. Chem. Phys., 10, 11359-11371, doi:10.5194/acp-1011359-2010, 2010.

Slemr, J.: Determination of volatile carbonyl compounds in clean air, Fresenius J. Anal. Chem., 340, 672-677, doi:10.1007/BF00321533, 1991.

Sommariva, R., Haggerstone, A.-L., Carpenter, L. J., Carslaw, N., Creasey, D. J., Heard, D. E., Lee, J. D., Lewis, A. C., Pilling, M. J., and Zádor, J.: $\mathrm{OH}$ and $\mathrm{HO}_{2}$ chemistry in clean marine air during SOAPEX-2, Atmos. Chem. Phys., 4, 839-856, doi:10.5194/acp-4-839-2004, 2004.

Stavrakou, T., Müller, J.-F., De Smedt, I., Van Roozendael, M., Kanakidou, M., Vrekoussis, M., Wittrock, F., Richter, A., and Burrows, J. P.: The continental source of glyoxal estimated by the synergistic use of spaceborne measurements and inverse modelling, Atmos. Chem. Phys., 9, 8431-8446, doi:10.5194/acp-98431-2009, 2009.

Steele, P., Krummel, P., van der Schoot, M. V., Spencer, D. A., Baly, S. B., Langenfelds, R. L., Howden, R. T., Ward, J., Somerville, N. T., and Cleland, S. J.: Baseline carbon dioxide monitoring, Baseline Atmospheric Program (Australia) 2009-2010, edited by: Derek, N., Krummel, P. B., and Cleland, S. J., Australian Bureau of Meteorology and CSIRO Marine and Atmospheric Research, Melbourne, 3941, available at: http://www.bom.gov.au/inside/cgbaps/baseline/ Baseline_2009-2010.pdf, last access: 22 August 2014.

Tan, Y., Lim, Y. B., Altieri, K. E., Seitzinger, S. P., and Turpin, B. J.: Mechanisms leading to oligomers and SOA through aqueous photooxidation: insights from $\mathrm{OH}$ radical oxidation of acetic acid and methylglyoxal, Atmos. Chem. Phys., 12, 801-813, doi:10.5194/acp-12-801-2012, 2012.

Thalman, R., Baeza-Romero, M. T., Ball, S. M., Borrás, E., Daniels, M. J. S., Goodall, I. C. A., Henry, S. B., Karl, T., Keutsch, F. N., Kim, S., Mak, J., Monks, P. S., Muñoz, A., Orlando, J., Peppe, S., Rickard, A. R., Ródenas, M., Sánchez, P., Seco, R., Su, L., Tyndall, G., Vázquez, M., Vera, T., Waxman, E., and Volkamer, R.: Instrument inter-comparison of glyoxal, methyl glyoxal and $\mathrm{NO}_{2}$ under simulated atmospheric conditions, Atmos. Meas. Tech. Discuss., 7, 8581-8642, doi:10.5194/amtd-7-8581-2014, 2014.

Topping, D., Connolly, P., and McFiggans, G.: Cloud droplet number enhanced by co-condensation of organic vapours, Nat. Geosci., 6, 443-446, doi:10.1038/ngeo1809, 2013.

van Pinxteren, M. and Herrmann, H.: Glyoxal and methylglyoxal in Atlantic seawater and marine aerosol particles: method development and first application during the Polarstern cruise ANT XXVII/4, Atmos. Chem. Phys., 13, 11791-11802, doi:10.5194/acp-13-11791-2013, 2013.
Volkamer, R.: Measurements of Bromine Oxide, Iodine Oxide and Oxygenated Hydrocarbons in the Tropical Free Troposphere from Research Aircraft and Mountaintops, NOAA ESRL Global Monitoring Annual Conference 2014, Boulder, Colorado, 2014.

Vrekoussis, M., Wittrock, F., Richter, A., and Burrows, J. P.: Temporal and spatial variability of glyoxal as observed from space, Atmos. Chem. Phys., 9, 4485-4504, doi:10.5194/acp-9-44852009, 2009.

Wang, H.-L., Zhang, X., and Chen, Z.-M.: Development of DNPH/HPLC method for the measurement of carbonyl compounds in the aqueous phase: applications to laboratory simulation and field measurement, Environ. Chem., 6, 389-397, doi:10.1071/EN09057, 2009.

Westervelt, D. M., Moore, R. H., Nenes, A., and Adams, P. J.: Effect of primary organic sea spray emissions on cloud condensation nuclei concentrations, Atmos. Chem. Phys., 12, 89-101, doi:10.5194/acp-12-89-2012, 2012.

Wilson, S. R.: Characterisation of $J\left(\mathrm{O}^{1} \mathrm{D}\right)$ at Cape Grim 2000-2005, Atmos. Chem. Phys. Discuss., 14, 18389-18419, doi:10.5194/acpd-14-18389-2014, 2014.

Wittrock, F., Richter, A., Oetjen, H., Burrows, J. P., Kanakidou, M., Myriokefalitakis, S., Volkamer, R., Beirle, S., Platt, U., and Wagner, T.: Simultaneous global observations of glyoxal and formaldehyde from space, Geophys. Res. Lett., 33, L16804, doi:10.1029/2006g1026310, 2006.

Zahorowski, W., Griffiths, A. D., Chambers, S. D., Williams, A. G., Law, R. M., Crawford, J., and Werczynski, S.: Constraining annual and seasonal radon-222 flux density from the Southern Ocean using radon-222 concentrations in the boundary layer at Cape Grim, Tellus B, 65, 19622, doi:10.3402/tellusb.v65i0.19622, 2013.

Zhou, S., Gonzalez, L., Leithead, A., Finewax, Z., Thalman, R., Vlasenko, A., Vagle, S., Miller, L.A., Li, S.-M., Bureekul, S., Furutani, H., Uematsu, M., Volkamer, R., and Abbatt, J.: Formation of gas-phase carbonyls from heterogeneous oxidation of polyunsaturated fatty acids at the air-water interface and of the sea surface microlayer, Atmos. Chem. Phys., 14, 1371-1384, doi:10.5194/acp-14-1371-2014, 2014.

Zhou, X. and Mopper, K.: Apparent partition coefficients of 15 carbonyl compounds between air and seawater and between air and freshwater; implications for air-sea exchange, Environ. Sci. Technol., 24, 1864-1869, doi:10.1021/es00082a013, 1990. 